\title{
Desafio estratégico da política pública: o ensino superior brasileiro*
}

\author{
Edson Nunes**
}

SuMÁRIo: 1. Introdução; 2. Ensino superior e política pública: o público e o privado como setores complementares e distintos; 3. Educação superior no Brasil: crescimento recente, mas insuficiente; 4. Expansão da educação superior através do setor privado; 5 . O setor privado com finalidade lucrativa, uma particularidade brasileira?; 6. Diversificação da educação superior: inovações e permanências; 7. Educação superior: profissionalização precoce e conteúdos impertinentes; 8. Economia política, arena política: um setor novo em ação; 9. Dilemas estratégicos da administração pública; 10. Sob a forma de conclusão: passados consagrados, futuros alternativos.

SUMMARY: 1. Introduction; 2. Higher education and public policy: the public and private as complementary and distinctive sectors; 3 . Higher education in Brazil: recent but insufficient growth; 4. Higher education expansion by the private sector; 5 . Profit-oriented private sector, a Brazilian trait?; 6. Higher education diversification: innovation and permanence; 7. Higher education; precocious professionalization and impertinent contents; 8. Political economy, political arena: a new sector in action; 9. Public policy strategic dilemmas; 10 . As to conclude: renowned pasts; alternative futures.

Palavras-Chave: ensino superior; políticas públicas; ensino superior privado.

\footnotetext{
* Este artigo, recebido e aceito em jun. 2007, reflete a pauta de trabalho do Observatório Universitário da Universidade Candido Mendes (www.observatoriouniversitario.org.br) e insere-se num programa mais amplo de pesquisas sobre política pública e educação superior. André Magalhães Nogueira e Violeta Maria Monteiro contribuíram para a preparação deste artigo de modo a merecerem a efetiva co-autoria, sem, contudo, poderem ser responsabilizados pelos erros eventuais, imperfeições e possíveis sugestões incabíveis aqui inscritas. Helena Maria Barroso e Ivanildo Fernandes prestaram valioso apoio, além de críticas e comentários fundamentais.

** PhD em ciência política pela UC-Berkeley, mestre em ciência política pelo Iuperj, bacharel em direito e em ciências sociais pela UFF. Presidente do Conselho Nacional de Educação, professor e pró-reitor da Universidade Candido Mendes. Endereço: Rua da Assembléia, 10, sala 4205 — CEP 20011-901, Rio de Janeiro, RJ, Brasil. E-mail: e-nunes@uol.com.br.
} 
KEY WORDS: higher education; public policies; private higher education.

Poucas pessoas no Brasil são, em comparação com países desenvolvidos, portadoras de diploma de ensino superior. Admitindo-se que a qualificação da população do país, a este nível, constitua interesse estratégico nacional, este artigo examina as características do caso brasileiro e discute as opções pregressas que o país fez, bem como observa as opções futuras, que estariam abertas ao país. O Brasil deliberou, ainda que não tenha manifestado claramente tal deliberação, por expandir seu ensino terciário por meio do setor privado. Desde o final do século XX esta expansão vem adquirindo uma faceta mercantil. Ao Estado brasileiro, contudo, apetece a estratégia da "não-decisão". Escolhe o setor privado para expandir a oferta de educação superior. E escolhe a via comercial, a partir de 1997, para fazê-lo. Mas não revela tal escolha. Deixa-a ao sabor, senão olhar, do analista das políticas públicas. Resta analisar as consequiências desta "não-decisão" brasileira. Este artigo oferece números, argumentos e sugestões sobre o tema.

Public policy strategic challenge: Brazilian higher education

Few people in Brazil, compared to developed countries, have a higher education diploma. Admitting that the qualification of the country's population at this level may constitute a national strategic interest, this article examines the characteristics of the Brazilian case and discusses the country's past choices, as well as the future ones that could be at its disposal. Brazil has decided, even thought not explicitly, to expand its tertiary education by means of the private sector. Since the end of the 20th century, this expansion has been gaining a mercantile facet. The Brazilian state, however is interested in a 'non-decision' strategy. It chooses the private sector to expand the offer of higher education. And since 1997 it has chosen the commercial path to do it. But it does not reveal this choice, leaving it to be examined according the perspective of the public policy analyst. One can only analyze the consequences of this Brazilian 'non-decision.' This article provides numbers, arguments and suggestions pertaining the issue.

\section{Introdução}

Observados os sumários de todos os exemplares da Revista de Administração Pública (RAP), nestes seus 40 anos de vida, contabilizam-se 1.579 artigos publicados. Registre-se que, deste total, menos de $8 \%$ (124) trataram da educação, sendo que pouco mais da metade disso, 68 (4,3\%), ocupou-se do ensino superior. Subtraindo-se deste número os 12 artigos que trataram especificamente da Escola Brasileira de Administração Pública e de Empresas da Fundação Getulio Vargas (Ebape/FGV), restam 56 artigos sobre o tema da educação 
superior. Em quatro décadas da $R A P$, um número equivalente a 3,5\% dos artigos desta publicação especializada abordou a educação superior. ${ }^{1}$

Considerando-se esta pequena percentagem como proxy da relevância do tema "educação superior" no imaginário da produção acadêmica de estudiosos e observadores do setor público, seria possível concluir que a questão tem pequena relevância para a área de estudos e pesquisas dedicada à reflexão sobre a administração e as políticas públicas nacionais. Conseqüentemente, seria bem possível concluir que a questão representa um "não-desafio" para a administração pública brasileira.

Consultados os programas de cursos de administração pública, ciência política e políticas públicas, bem como compulsados cursos e livros sobre direito administrativo, será possível concluir, ainda, que a questão "educação superior", do ponto de vista regulatório, estratégico ou administrativo, é em verdade um "não-assunto" ou "não-tema". E isso, ressalte-se, considerando-se a área de saber dos que se dedicam à formação profissional relacionada à administração pública e dos que vêem a educação, sob tal ótica disciplinar, como um instrumento fundamental para o desenvolvimento socioeconômico do país.

\section{Ensino superior e política pública: o público e o privado como setores complementares e distintos}

Submeto que há algo de errado acontecendo. Está ausente um assunto crucialmente estratégico para o país e, portanto, para sua administração e suas políticas públicas. Falta analisar a educação superior como um dos mais importantes e cruciais temas operacionais e estratégicos da nação e do Estado brasileiro. Por alguma razão, que não procuraremos explicar, apenas constatamos, o conjunto de decisões tomadas pela administração pública brasileira sobre o ensino superior nunca foi adequadamente codificado pelo governo

\footnotetext{
${ }^{1}$ Os critérios utilizados na seleção dos artigos acadêmicos foram os que se seguem. Em um primeiro momento, a classificação temática teve por base palavras-chave de título (por exemplo: educação, ensino, universidade, formação, aprendizado, professor, escola). A seguir, o conteúdo dos artigos selecionados foi analisado com base no sumário e/ou na introdução do artigo, sendo os textos, então, agrupados em quatro grandes áreas: questões organizacionais (mudança, planejamento e financiamento); formação de nível superior (ensino e mercado de trabalho); educação superior (administração e políticas públicas); Ebape, onde foram classificados os artigos sobre a escola, seus alunos e suas experiências.
} 
como tal, alojando-se, talvez, naquela categoria das "decisões não formuladas", ou "não-decisões" que, entretanto, produzem efeitos constantes e permanentes. Por exemplo, busque-se em qualquer discurso de dirigente nacional, em qualquer momento da história recente, evidência de que houve decisão de expandir o ensino superior através do setor privado. Não se encontrará a decisão, muito menos se precisará o momento de sua efetivação. Mas observandose a série histórica sobre o setor, será possível constatar a decisão incremental, talvez, mas permanente, repetida e segura de efetivar a expansão da educação superior mediante investimentos privados.

O país deliberou — ou vem deliberando, se preferirmos — expandir seu ensino superior por meio do setor privado. Mas não tomou um conjunto de outras medidas necessárias a, de um lado, tirar vantagens desta deliberação, e, de outro, adequadamente administrar suas premissas e conseqüências. Do ponto de vista administrativo, vivemos em um "ambiente-tarefa"2 desgovernado, porque o problema em tela não pode ser plena e racionalmente reconhecido pela administração pública, a não ser sob o crivo da crítica ideológica, com retórica e verbos à sinistra. Isso porque a administração pública brasileira não quis, não pôde, ou preferiu não dizer explicitamente o que fez historicamente, mesmo nesta quase década e meia de social-democracia com tinturas de PSDB e PT: a deliberação de escolher o setor privado como esteio da não-política, da nãodecisão brasileira de expandir o sistema de educação superior por tal caminho.

Tal deliberação - verdade desnuda — vem acompanhada de outro conjunto de microdeliberações aparentemente contraditórias à decisão central, que entendem o aparato regulatório e de supervisão como um fim em si mesmo. Por isso o governo, nestes três últimos mandatos presidenciais, vem se debruçando sobre a produção de minudente e caudaloso processo microrregulatório, mais destinado a controlar e interpelar o setor privado do que a tirar vantagem da robusta realidade de sua existência. ${ }^{3}$ Ora, primeiro o Brasil decidiu crescer sua oferta de ensino superior à base do setor privado; em seguida deliberou por estimular a existência de empresas educacionais com finalidades lucrativas; mas, por fim, em significativa esquizofrenia institucional, resol-

\footnotetext{
2 Permitam tal tradução de task environment, tema conhecido na administração pública e nos estudos organizacionais. Para exemplo clássico, ver Scott (1981), especialmente a seção intitulada "Managing task environments" (p. 188).

${ }^{3}$ O Observatório Universitário da Universidade Candido Mendes (www.observatoriouniver sitario.org.br) tem divulgado estudos sobre as políticas públicas para a educação superior, no que se refere às vicissitudes microrregulatórias. A esse respeito, ver, especificamente, Nunes et al. (2005).
} 
veu ignorar que o setor privado - principalmente o mercantil - e o setor público constituem nichos institucionais alternativos e complementares, mas diferentes, com dinâmicas e estruturas organizacionais distintas e, sobretudo, com finalidades, culturas e objetivos organizacionais distintos. A taxonomia institucional existente - bem como a base regulatória dela recorrente - ignora as importantes fronteiras que separam e caracterizam um setor mercantil, em contraste com o setor público, ou com o setor verdadeiramente comunitário e sem fins lucrativos.

O governo classifica as instituições de ensino superior (IES) conforme dois critérios: organização acadêmica e categoria administrativa. O primeiro critério, que se refere à estruturação das instituições, distingue os seguintes tipos: universidades, centros universitários, centros federais de educação tecnológica, faculdades integradas, faculdades e institutos ou escolas superiores. Tais tipos podem ser agrupados em dois grupos: as instituições universitárias, que congregam universidades e centros; e as instituições não-universitárias, englobando os demais.

A categoria administrativa, embora seja um critério atribuído às IES (mantidas), de fato manifesta a situação das mantenedoras. Há dois grupos básicos, cada qual com subdivisões: instituições públicas e privadas. As públicas são classificadas em instituições federais, estaduais ou municipais, dependendo da instância de governo à qual estejam vinculadas. As privadas dividem-se em comunitárias, confessionais, filantrópicas e particulares, sendo que as três primeiras referem-se a IES mantidas por instituições sem fins lucrativos. Já as particulares incluem tanto as IES vinculadas a mantenedoras com fins lucrativos, que seriam particulares em sentido estrito, quanto as mantidas por entidades sem fins lucrativos, mas que não se enquadrem no tipo filantrópico. ${ }^{4}$

\footnotetext{
${ }^{4}$ As estatísticas históricas publicadas pelo Inep no Censo da Educação Superior não permitem distinguir, com precisão, no grupo de IES particulares quais são de fato as com finalidade lucrativa. Em primeiro lugar, porque há uma legislação variada incidindo sobre a questão. A Lei $\mathrm{n}^{2} 11.096 / 2005$, que instituiu o ProUni, separa as IES em dois grupos: um é o das com fins lucrativos e das sem fins lucrativos não-beneficentes, e outro o das beneficentes, que precisam ter certificado de entidade beneficente de assistência social, concedido pelo Conselho Nacional de Assistência Social e renovável por três anos. Sobre esta última questão, há a Lei $\mathrm{n}^{2} 8.212$, de 24 de julho de 1991, que trata da organização da seguridade social, modificada pela Lei $\mathrm{n}^{\circ}$ 9.429, de 26 de dezembro de 1996, a qual alterou o requisito para posse do certificado e do registro de entidade de fins filantrópicos. Assim, há instituições sem fins lucrativos classificadas como particulares, que não são filantrópicas, bem como há mantenedoras com certificado do CNAS que não são confessionais, nem religiosas, mas que têm o mesmo status. Em segundo lugar, desde a Lei n 9.870, de 23 de novembro de 1999, que alterou a redação da Lei n 9.131,
} 
Enunciemos desde já o que todo estudante de administração pública e de sistemas organizacionais complexos sabe como corolário: organizações com finalidades diferentes tendem a ser baseadas em culturas distintas e baseadas em estruturas diferentes para a perfeita consecução de seus fins. ${ }^{5}$ Ou seja, a função desempenhada, ou buscada, por uma organização complexa tende a definir sua estrutura, e não o contrário. Não é a estrutura que define a função, mas sim a função que define a estrutura, principalmente em organizações de inteligência. Portanto, IES com fins lucrativos nunca serão, desde o ponto de vista institucional/organizacional, estruturalmente semelhantes às públicas, a despeito de assim determinar o aparato micro (senão nano) regulatório legal e governamental. Sob o atual modelo regulatório, as entidades privadas são forçadas e aderir a modelos estruturais e de governança corporativa originalmente desenhados para o setor público. Engana-se, contudo, o governo, se acha que tal metamorfose é possível ou eficiente. Nenhuma organização com finalidade lucrativa poderá ser igual a nenhuma organização pública, porque os fins de uma e de outra tendem a determinar suas estruturas e funcionamento, a despeito de qualquer enunciado regulatório. Ao insistir nisso, a pauta regulatória governamental acaba tendo de se contentar com uma ficção que bem sabe ser imprópria, mas sobre a qual insiste.

Universidades e instituições de ensino superior lucrativas e públicas são, aos olhos da administração pública brasileira, animais idênticos, aparentemente, porque ambas militam na oferta de educação superior. Entretanto, se observados os valores implementados pelos aparatos organizacionais, a cultura nos quais se apóiam, as finalidades que buscam, o produto que geram, será possível dizer exatamente o contrário: embora os dois tipos de instituição militem na oferta de ensino superior, elas acabam constituindo entidades fundamentalmente distintas e, certamente, complementares desde o ponto de vista global e estratégico, desde que sejam percebidas como diferentes.

de 24 de novembro de 1995, as mantenedoras privadas podem assumir qualquer das formas admitidas em direito, de natureza civil ou comercial. Assim, tornou-se possível modificar sua natureza a qualquer tempo, o que pode alterar aspectos das séries históricas, dando a entender que houve criação de novas IES, quando pode ter ocorrido uma modificação na personalidade jurídica das mantenedoras. Como conseqüência disso, embora a medida estimule a existência de entidades com fins lucrativos, os números oficiais ainda não permitem distingui-las claramente. Os números que se apresentam à frente requereram atenção e gentileza especial de técnicos do Inep.

${ }^{5}$ A este respeito é compulsória a leitura do clássico de Charles Perrow, Complex organizations (Perrow, 1979). 
No Brasil, existem as instituições mantenedoras e as mantidas. As últimas são as instituições responsáveis pela oferta de ensino, respondendo perante os órgãos públicos de regulação, avaliação e supervisão pelas questões estritamente educacionais. Já as mantenedoras, ao contrário das mantidas, têm personalidade e responsabilidade jurídicas, sendo titulares de questões administrativas, econômico-financeiras e patrimoniais diante dos órgãos públicos, educacionais ou não, e também com relação a discentes, docentes e pessoal técnico-administrativo. Nesse sentido, a natureza de ser lucrativa ou não-lucrativa de uma IES decorre antes da condição de sua mantenedora.

Diante do exposto e para efeitos analíticos, as instituições atuantes na educação superior podem ser dispostas, com respeito à questão da lucratividade, em um contínuo que varia entre dois limites. De um lado, estão as instituições estritamente de mercado, ou seja, voltadas à obtenção de lucro a ser distribuído aos seus proprietários (investidores) e que se mantêm a partir de recursos privados obtidos pela oferta de seus serviços. Do outro, estão as públicas e as não-lucrativas em sentido estrito, isto é, as instituições que dependem de recursos públicos, diretos ou indiretos (renúncias fiscais) ou de doações privadas, para efetivar suas atividades educacionais. Entre esses dois extremos, situam-se variantes institucionais, como IES que são remuneradas pela oferta dos seus serviços (ensino pago), que obtêm recursos públicos diretos ou indiretos, mas que renunciam à lucratividade, reinvestindo os recursos excedentes em suas atividades educacionais.

Ressalvando-se que as realidades nacionais admitem diferenças, é possível, com base em adaptação de sumário da literatura corrente, ${ }^{6}$ observar quais seriam os traços típicos que distinguem as entidades lucrativas das não-lucrativas. De uma maneira geral, e com as ressalvas de praxe no que se refere às características culturais e legais, as IES não-lucrativas, no que diz respeito a aspectos econômicos e financeiros, desfrutam de benefícios fiscais e dependem da doação de recursos de pessoas físicas e jurídicas, tendo, por isso, stakeholders envolvidos com sua sustentabilidade. Já as IES estritamente lucrativas, além de não ter acesso a recursos públicos diretos e indiretos (bene-

\footnotetext{
${ }^{6}$ Ver discussão sobre o tema em Ruch (2001). Importante análise, com claro valor comparativo para o Brasil deve ser lida em Chanana (2006). Nesse volume existem, também com relevante interesse comparativo para nós que temos pesado componente privado e lucrativo na educação superior, artigos sobre vários países da região. Para nós, Filipinas e Japão constituem referências importantes por esta razão. Se neste livro o capítulo sobre o Japão, desde o ponto de vista estratégico, pode nos causar inveja, esta fica totalmente relativizada pela devastadora análise da educação superior japonesa apresentada por McVeigh (2002).
} 
fícios fiscais), extraem sua sustentabilidade da oferta de seus serviços, apoiando-se em seus investidores privados, que se mantêm como acionistas, desde que assegurada sua lucratividade.

É possível estabelecer outra distinção do ponto de vista administrativo. A gestão das IES lucrativas fundamenta-se em práticas de mercado consagradas, não se diferenciando de regras administrativas adotadas em entidades não-educacionais. Já as não-lucrativas geralmente têm gestão compartilhada, sendo caracterizadas pela presença de órgãos colegiados e pela presença de práticas e hábitos afins aos de organizações do terceiro setor.

Do ponto de vista educacional, as não-lucrativas estão motivadas pela obtenção de prestígio institucional, produção de conhecimento mesmo se não aplicado a fins práticos, concentrando-se na formação acadêmica de seus discentes e no desenvolvimento das carreiras de seus docentes, os quais possuem influência institucional significativa. Já as lucrativas têm ensino aplicado e fortemente influenciado pelo mercado, no que se refere tanto à formação acadêmica de seus alunos, quanto à seleção de seus docentes. Finalmente, em termos de sua orientação fundamental, as universidades públicas e as não-lucrativas, americanas, claro, seriam discipline-oriented - perdoando-se os anglicismos todos -, ou seja, há predominância das disciplinas científicas na orientação vital da instituição, de seus docentes e pesquisadores, governadas por aquilo que a literatura especializada em sociologia da ciência chamou de um invisible college, enquanto as lucrativas não se orientariam por matriz disciplinar.

O processo decisório incremental que foi utilizado na escolha do setor privado como esteio e alavanca da expansão do ensino superior pode ter várias e relevantes conseqüências para o país, sejam elas estratégicas, regulatórias ou administrativas. Precisa ser aceito como decisão efetivamente institucionalizada, de modo, então, que se providenciem as adequadas discussões sobre este "nãoevento" da política pública brasileira. E mais, que se elimine o véu de silêncio sobre o tema, passando-se, então, a discutir as necessárias e pertinentes decisões efetivas, estratégicas, regulatórias, administrativas. Isso para que possa ser assegurado, no futuro, o adequado tratamento da presente realidade, a qual pode produzir conseqüências importantes e positivas, se bem administradas, ou certamente deletérias, se governadas sob o véu da ignorância.

A distinta natureza das entidades lucrativas e públicas oferece a virtuosa possibilidade que se explore uma eventual divisão social do trabalho institucional em benefício do país, ${ }^{7}$ o que, certamente, exigirá profundas e racionais

\footnotetext{
${ }^{7}$ O tema da divisão social do trabalho institucional, particularmente aplicado ao trabalho de pesquisa científica, inspirado no clássico original de Durkheim, foi estudado em Nunes (1977).
} 
reformas das bases regulatórias e de supervisão governamental para o setor. Caberia ao setor público a responsabilidade com os fundamentos da vida universitária e científica, através de suas mantidas, que não deveriam ser compelidas à participação no processo de massificação da educação superior, para que possam se dedicar à orientação disciplinar fundamentalmente acadêmica e científica, portanto universitárias no mais estrito sentido do termo. Caberia ao setor privado a oferta massificada de ensino de boa qualidade, adequadamente supervisionado e avaliado, sem que se esperasse dele dedicação ao avanço da ciência e a aderência a valores imateriais e históricos, dele esperando-se, contudo, a adequada atenção à formação profissional nas suas diferentes modalidades. A cada qual, portanto, o reconhecimento e estímulo à sua função. Ao país, o benefício de reconhecer a divisão social do trabalho institucional e de se beneficiar da possibilidade de investir em universidades de classe mundial, sem a necessária preocupação com a massificação do ensino superior.

Registremos, portanto, a magnitude e a relevância do problema trazido pela necessidade de expansão do ensino superior no Brasil, já com antecipado pedido de entendimento do leitor de que o argumento a ser desenvolvido exigirá, ainda que de forma sucinta, a apresentação de dados, com o objetivo de apontar os traços da presente realidade, que exige pertinente e adequado tratamento por parte da administração e da política pública brasileira.

\section{Educação superior no Brasil: crescimento recente, mas insuficiente}

A educação superior no país é um acontecimento tardio. A rigor, remonta há pouco menos de dois séculos, quando, em 1808, a família real portuguesa chegou ao Rio de Janeiro, afastando-se das guerras napoleônicas. Foi justamente a necessidade de se organizar a Corte, formando quadros administrativos na então Colônia, que levou à criação dos primeiros cursos superiores.

Resumidamente, houve três características marcantes nesse processo de estruturação do setor que se mantiveram até o século seguinte. Primeiro, houve a ascendência do governo central sobre as províncias (e posteriormente estados) e sobre as iniciativas particulares. As chamadas escolas ou faculdades livres precisavam ser equiparadas, por ato do governo, às oficiais, para que pudessem gozar de prerrogativas como a concessão de grau superior. Nesse sentido, o molde, o formato de estruturação da educação superior, foi derivado do governo federal. 
A segunda característica foi a de ser um ensino nascido para a formação e reprodução de elites. Inicialmente, dadas as necessidades da burocracia civil e militar, foram criados os cursos de medicina, direito e engenharia, as chamadas profissões imperiais (Coelho, 1999). Observe-se que tal caráter elitista também refletia os baixos níveis de escolaridade da população brasileira. Apenas ao longo do século XX, notadamente na segunda metade, é que a educação superior foi se expandindo para os segmentos médios da população, fenômeno facilitado pela ascensão das corporações e pela regulamentação das profissões vinculadas à educação superior, com os privilégios e prerrogativas decorrentes.

A terceira característica foi a opção inicial pela estruturação da educação a partir de faculdades e escolas isoladas. O desenvolvimento do ensino universitário iniciou-se apenas a partir da década de 1930, fortalecendo-se nos anos 1960, com a Lei de Diretrizes e Bases (LDB) de 1961 e a reforma de 1968. Na reforma dos anos 1930, introduziu-se a sistemática de autorização e reconhecimento de cursos e instituições, mediante a qual o governo federal regulava e controlava a expansão do setor. Registre-se que, na segunda metade do século XX, começou, por assim dizer, a se desenhar uma primeira divisão de trabalho institucional, predominando nos setores públicos federal e estaduais o formato universitário, e no setor privado as faculdades isoladas e integradas.

A tentativa de transformação da educação superior de um sistema elitista para um massificado ${ }^{8}$ começou a se construir na década de 1960. Ainda hoje, contudo, o sistema brasileiro continua a ser elitizado, a despeito de sua freqüentemente criticada, mas indispensável, rápida expansão. Em 1908, segundo dados do Anuário Estatístico do Brasil, havia 6.735 estudantes matriculados em instituições de educação superior. No ano de 1960, esse total somava 93.202 alunos, um incremento de $1.284 \%$ em pouco mais de cinco décadas. Vinte anos depois, em 1980, as matrículas na educação superior somavam 1.377.286, um aumento de $1.378 \%$ no período. Até a virada do milênio, conforme dados do Inep, tal número quase dobraria, atingindo 2.622 .073 matri-

\footnotetext{
${ }^{8}$ Na verdade, o sistema de educação superior do Brasil, cuja taxa de escolarização líquida está em torno de $11 \%$, está ainda se aproximando do limite inferior do que se classifica como um sistema massificado. Conforme categorização de Martin Trow, os sistemas educacionais são considerados de elite se a taxa de escolarização líquida for inferior a 15\%. Sistemas massificados são aqueles que variam entre $15 \%$ e $33 \%$ (um terço). Acima disso, são classificados como sistemas universais. A taxa de escolarização líquida expressa a razão do total de estudantes com idades correspondentes ao nível de educação em que se inserem sobre o total da população na mesma faixa etária. No caso da educação superior, podem ser utilizadas as faixas que variam da idade mínima de 18 até o máximo de 25 anos. Sobre a categorização, ver Trow (1974).
} 
culados em 2000. Considerando-se a última estatística disponível (2005), há 4.453.156 estudantes de ensino superior, ou seja, em menos de 100 anos o total de matrículas é 661 vezes maior.

A despeito desses números significativos, o Brasil ainda ocupa uma posição frágil, senão vexatória, quando se comparam os números relativos a adultos brasileiros portadores de diploma superior com adultos de outros países selecionados. Ao final do século XX, com pouco mais de $6 \%$ da população adulta com educação superior, o Brasil se contrapunha ao Canadá, que, com cerca de 40\%, apresentava percentual superior ao dos Estados Unidos, Japão e de tantos outros países. A propósito, como demonstra a figura 1, diante desses números, recorrer a outros indicadores para entender o que mais nos separa desses países em termos de qualidade vida, capacidade técnica, índices de desenvolvimento humano ou, mesmo, para evidenciar o enorme hiato que nos distancia é quase um pleonasmo. Afinal, a média para os países da OCDE aproxima-se dos $25 \%$ do total da população adulta com educação superior.

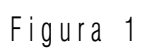

Percentagem das pessoas entre 25 e 64 anos de idade com educação superior completa (Brasil e países da OCDE, 2000)

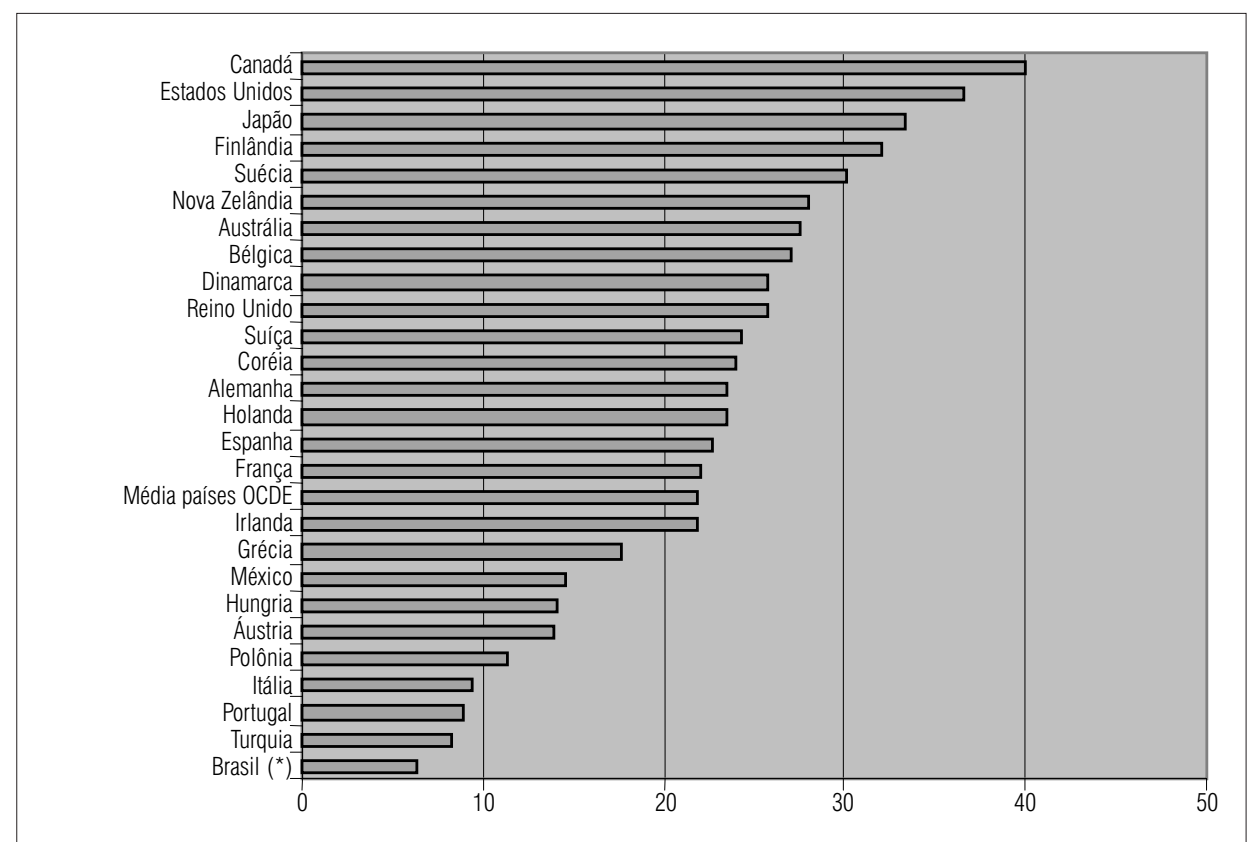

Fontes: OECD (2006); IBGE, Censo Demográfico 2000, e população de 23 anos ou mais. ${ }^{\star} 23$ anos ou mais. 
Poder-se-ia argumentar que o país tanto se preocupa com o problema que aprovou, em 2001, sob a forma da Lei no 10.172, de 10 de janeiro desse ano, o Plano Nacional de Educação (PNE). Ademais, em 2006, foi proposto pelo Executivo o Projeto de Lei no 7.200, estabelecendo normas gerais da educação superior e regulando a educação superior no sistema federal de ensino, no que ficou conhecido, ao longo de sua discussão com a sociedade, como "Projeto de Reforma Universitária". Tal proposta encontra-se, no presente, tramitando na Câmara dos Deputados, aparentemente sem nenhum esforço especial por parte do Executivo para sua aprovação. O PL no 7.200/2006, embora proposto como uma lei orgânica para a educação superior (Loes) que regulasse o sistema federal de ensino, dedicava atenção maior a estabelecer normas para o setor privado.

No ano em curso, também foi proposto pelo governo federal o Plano de Desenvolvimento da Educação (PDE), que ora se encontra em fase de formatação das propostas. O site do MEC registra a existência de 29 ações/ projetos associados ao $\mathrm{PDE}$, a minoria das quais relacionadas ao ensino superior. Para este nível, contudo, o PDE propõe dobrar, em 10 anos, o número de vagas oferecidas pelas universidades federais. Para tanto, foi criado o Programa de Apoio a Planos de Reestruturação e Expansão das Universidades Federais (Reuni), através do Decreto ํㅡ 6.096, de 24 de abril de 2007, com o objetivo de criar condições para a ampliação do acesso e permanência na educação superior, no nível de graduação, pelo melhor aproveitamento da estrutura física e de recursos humanos existente nas universidades federais.

Ressalve-se, a propósito, que o PNE de 2001 contemplava, como uma de suas metas, matricular em instituições de educação superior, até 2010, um número de estudantes equivalente a $30 \%$ da coorte entre 18 e 23 anos, o que faria o país inserir-se no grupo de sistemas massificados e próximo ao seu limite superior (33\%), ou seja, na fronteira com o grupo de países classificados como sistemas universais. Atualmente, este número está em torno de $11 \%$, o que atesta que tal meta dificilmente será alcançada no prazo desejado. Ora, ainda que a isso se chegasse, seria uma conquista modesta em termos comparados, uma vez que vários países estão, hoje, se aproximando da matrícula de $50 \%$ da mesma coorte em educação superior, ou seja, em sistemas classificados como universais. Ademais, mesmo que atingíssemos tal meta de fluxo, ainda teríamos pequeno estoque, em termos comparados, de adultos com educação superior. 
No que se refere à educação superior, o PNE não passava de uma carta de intenções, um registro de desejo futuro sem previsão dos recursos necessários, sem definição de uma estratégia de administração pública, sem atribuição de responsabilidades para o cumprimento da meta sonhada. Já a Loes manifesta-se antes como uma proposta de aparato regulatório para o setor privado, na assunção de que constitui réplica do público. Por seu turno, o PDE, no que se atém à educação superior, concentra-se na reestruturação das universidades federais, sob o suposto de que tenham papel decisivo no processo de massificação.

Assim, pouco se faz para lidar com desafios fundamentais inerentes à desejável ascensão do país, e de sua educação superior, no contexto mundial. Solenemente ignora-se, por exemplo, o desafio de se aumentar a qualidade do setor público, de forma que se tenham universidades de classe mundial. Igualmente, permanece a dificuldade em se tratar da massificação e diversificação da educação superior que acontecem no setor privado. Reforçam tal percepção dois importantes fatores que influirão na trajetória de expansão do ensino superior brasileiro: as variações demográficas e a situação econômica da população que ainda não tem acesso à educação de terceiro grau.

$\mathrm{O}$ alunado de terceiro grau tem crescido consistentemente não apenas no Brasil, mas também em termos internacionais. Algumas projeções dão conta de que o número de estudantes matriculados em instituições de nível superior poderá dobrar até 2025. Porém, essa tendência poderá ser fortemente controlada - ou alterada - quando se consideram as tendências declinantes do crescimento demográfico nos países mais desenvolvidos, notadamente nos que integram a Comunidade Européia. O impacto desse cenário na educação superior não será, sem dúvida, uniforme. No caso brasileiro, considerando as projeções que demonstram a futura estabilização populacional na faixa dos 18 aos 24 anos, a expansão do ensino superior via crescimento populacional estará descartada (Martignoni, 2007).

Quanto à outra barreira, situação econômica da demanda potencial, observa-se que a renda média domiciliar dos que estão em idade de entrar em IES - mas que ainda estão fora - é menor do que a média dos que estão inseridos no sistema. A figura 2 mostra que, comparativamente, o perfil de renda domiciliar dos estudantes da educação superior é significativamente superior ao dos estudantes de nível médio, o que significa que, sem políticas de incentivo, dificilmente aumentará a taxa de escolarização. 
Figura 2

Distribuição percentual dos estudantes por nível educacional em andamento, segundo faixa de renda média domiciliar per capita no Brasil (2005)

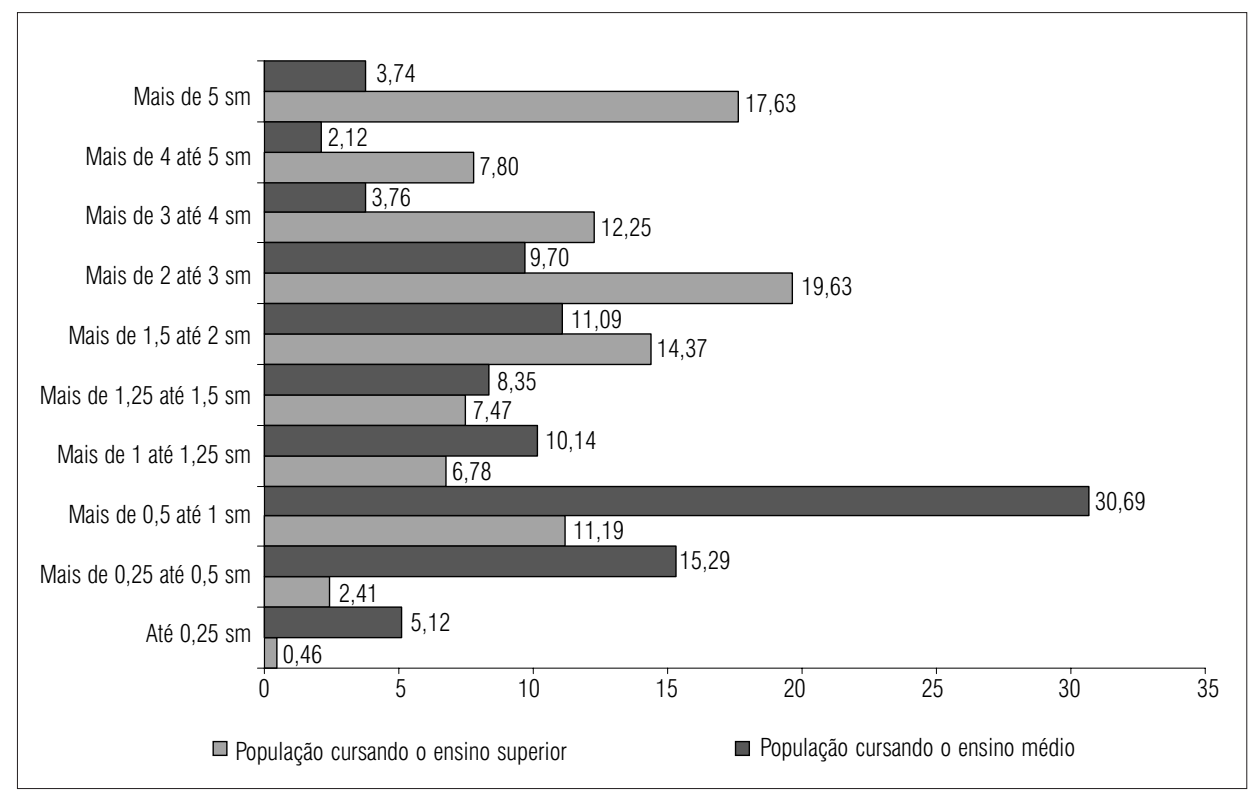

Obs.: sm = salário mínimo

\section{Expansão da educação superior através do setor privado}

Entre 1980 e 2005, o total de IES passou de 882 para 2.166, um crescimento de 145\%. Desse total mais recente, 231 são públicas e 1.934 privadas, ou seja, de cada 10 IES credenciadas, nove são privadas. No período, o incremento das instituições públicas foi de apenas 16\% (eram 200), taxa bem inferior aos $189 \%$ das privadas (havia 682). Não obstante o maior ritmo de aumento de instituições ter ocorrido no setor privado, isso não aconteceu de forma linear. Tomando por referência o ano de 1994, quando existiam 633 IES privadas, houve um decréscimo de 7\% em relação ao marco inicial. De fato, o grande salto no desenvolvimento do setor privado transcorreu no período de 1997 a 2005, fase que se seguiu à promulgação da nova LDB (Lei no 9.394, de 20 de dezembro de 1996).

A expansão da educação superior através do setor privado é ainda mais eloqüente quando analisados os dados referentes às matrículas. Em 2005, dos 
4.453.156 estudantes matriculados, 73\% (3.260.967) eram de IES privadas. No período entre 1980 e 2005, o incremento de matriculados no setor privado foi de $268 \%$, quase o dobro da taxa verificada no setor público (142\%). Em uma separação por fases, observa-se uma diferença marcante. Entre 1980 e 1994, houve um aumento de apenas $10 \%$ (de 885.054 a 970.584), enquanto na fase recente (1994-2005), o crescimento foi de $236 \%$.

A comparação entre as respectivas taxas de crescimento do número de instituições de educação superior e dos estudantes nelas matriculados revela que a destes últimos foi maior, especialmente no que se refere às IES privadas (189\% vs. 268\%). Controlando-se ambas as taxas pelas fases intermediárias, constata-se que mesmo havendo uma diminuição de $7 \%$ no número de instituições privadas entre 1980 e 1994, o total de matriculados aumentou 10\%.

Tal fato explica-se por uma mudança de tendência quanto ao porte das IES privadas. Ao final da década de 1980, especialmente após a Constituição de 1988, cresceu o interesse de mantenedores privados em constituir universidades, instituições de maior porte, que se organizam a partir da agregação de escolas e faculdades, ou seja, instituições antes contabilizadas isoladamente passam a integrar um novo tipo institucional. Esse fenômeno aumentou após a LDB de 1996 e sua regulamentação, quando foi criado, por decreto, um novo tipo de IES, os centros universitários, que passaram a gozar de certas prerrogativas de autonomia, como facilidade para a abertura de vagas e cursos. Somando-se a isso uma maior liberalidade para a criação de cursos e o credenciamento de instituições isoladas, chega-se ao crescimento vigoroso registrado na fase recente: $175 \%$ a mais de matriculados após a LDB (1997 a 2005).

Em termos internacionais, o Brasil é um dos casos singulares, por apresentar volume enorme de educação superior provida por entidades particulares independentes do Estado. ${ }^{9}$ Para que se tenha idéia do significado comparativo dessa decisão - ou não-decisão — estratégica, registre-se que

\footnotetext{
${ }^{9}$ Embora fundamental para o entendimento da realidade brasileira, é importante ver com cautela os dados disponíveis em termos internacionais que, normalmente, se utilizam de diferentes esquemas classificatórios e de diferentes fontes de informações primárias. Por exemplo, Taiwan não integra a lista da OCDE, mas pelos dados do Prophe (Program for Research on Private Higher Education), um dos mais respeitados centros de estudos sobre este segmento, teria respectivamente $72 \%$ de matrículas em instituições privadas em 2004. Por sua vez, em Israel, para o Profhe, há $13 \%$ de matrículas em 2005. Portanto, mesmo o pleno conhecimento do setor educacional não é suficiente para o correto entendimento do que os números significam. A análise da legislação educacional é fundamental, bem como a compreensão do contexto socioeconômico e cultural no qual se insere o sistema de educação.
} 
num universo de 50 países membros e não-membros para os quais a OCDE disponibiliza dados sobre a configuração da educação superior, em apenas 11, além do Brasil, o crescimento da educação superior tem sido suportado pelo setor privado. É importante registrar que na maioria desses países o processo, em seus primórdios, foi bastante semelhante ao que se observou no Brasil. O ponto de partida foi o enfraquecimento, ou mesmo esgotamento, da capacidade do Estado em prover a expansão do setor.

\begin{tabular}{|c|c|c|c|c|c|c|c|}
\hline \multicolumn{8}{|c|}{$\begin{array}{l}\text { Tabela } 1 \\
\text { Matrículas na educação superior por tipo de instituição (2003) }\end{array}$} \\
\hline \multirow[t]{2}{*}{ Matrículas } & \multirow[t]{2}{*}{ Total } & \multirow[t]{2}{*}{ Público } & \multirow[t]{2}{*}{ Privado } & \multicolumn{2}{|c|}{ Privado } & \multirow{2}{*}{$\begin{array}{c}\text { Privado/ } \\
\text { Total } \\
(\%)\end{array}$} & \multirow{2}{*}{$\begin{array}{c}\text { Privado } \\
\text { Indep./Priv } \\
(\%)\end{array}$} \\
\hline & & & & GovDep & Govlndep & & \\
\hline \multicolumn{8}{|c|}{ Países-membros } \\
\hline Bélgica & 374.532 & 166.041 & 208.491 & 208.491 & 0 & 55,67 & 0,00 \\
\hline Japão & 3.984 .400 & 915.651 & 3.068 .749 & 0 & 3.068 .749 & 77,02 & 100,00 \\
\hline Coréia & 3.223 .431 & 626.590 & 2.596 .841 & 0 & 2.596 .841 & 80,56 & 100,00 \\
\hline Holanda & 526.767 & 0 & 526.767 & 526.767 & 0 & 100,00 & 0,00 \\
\hline Reino Unido & 2.287 .833 & 0 & 2.287 .833 & 2.287 .833 & 0 & 100,00 & 0,00 \\
\hline \multicolumn{8}{|c|}{ Países não-membros } \\
\hline Brasil & 3.579 .252 & 1.135 .648 & 2.443 .604 & 0 & 2.443 .604 & 68,27 & 100,00 \\
\hline Chile & 567.114 & 146.119 & 420.995 & 100.631 & 320.364 & 74,23 & 76,10 \\
\hline Indonésia & 3.441 .429 & 1.340 .445 & 2.100 .984 & 0 & 2.100 .984 & 61,05 & 100,00 \\
\hline Israel & 301.326 & 47.427 & 253.899 & 228.046 & 25.853 & 84,26 & 10,18 \\
\hline Paraguai & 146.489 & 61.093 & 85.396 & 1.835 & 83.561 & 58,30 & 97,85 \\
\hline Peru & 830.345 & 440.930 & 389.415 & 2.200 & 387.215 & 46,90 & 99,44 \\
\hline Filipinas & 2.427.211 & 815.830 & 1.611 .381 & 0 & 1.611 .381 & 66,39 & 100,00 \\
\hline
\end{tabular}

A despeito de tal similaridade, em muitos desses países, a questão tem sido tratada de forma mais consciente quanto às respectivas responsabilidades das instituições de ensino e dos órgãos encarregados da regulação e supervisão educacional. Como conseqüência, os resultados têm sido extremamente positivos no que diz respeito à maior autonomia acadêmica e financeira e flexibilidade organizacional, bem como ao aumento do controle sobre os serviços oferecidos por organismos que, em sua maioria, não estão diretamente subordinados às instâncias governamentais. Tudo isso, cumpre reforçar, em um con- 
texto com menor imposição de instrumentos de regulação e supervisão, dado que o foco de ação do poder público está mais bem centrado nas questões prioritárias, quais sejam, fazer crescer quantitativamente o sistema, incentivando sua melhoria.

\section{O setor privado com finalidade lucrativa, uma particularidade brasileira?}

Outro fator distintivo do caso brasileiro é o estímulo recente à constituição de entidades educacionais com fins lucrativos. A existência de instituições de educação superior lucrativas é pouco tratada nas análises internacionais, apesar de o segmento estar em franco desenvolvimento. ${ }^{10}$ Nos países listados acima, em apenas um, além do Brasil, a existência de instituições de ensino superior lucrativas é explicitamente aceita (Filipinas). Em outros quatro não são admitidas instituições lucrativas e, nos demais, o assunto não é tratado na legislação pertinente. Observe-se, contudo, que mesmo em países onde o setor privado não é majoritário, como os Estados Unidos e a China, ${ }^{11}$ sua participação na educação superior é significativa, sendo expressivo o crescimento das instituições lucrativas no passado recente.

Nas normas legais brasileiras atinentes à educação superior, apenas em 1997, com a edição da Medida Provisória no 1.477-39, de 8 de agosto, e do Decreto no 2.306 , de 19 de agosto, foi aprovado o ato que explicitamente previa que o setor privado educacional poderia se organizar com finalidades lucrativas. ${ }^{12}$ A Reforma Universitária de 1968, principal norma vigente até a edição

\footnotetext{
${ }^{10}$ A finalidade lucrativa no ensino superior é fenômeno recente no mundo e desperta os mais e interessantes, senão imperdíveis, debates, do ponto de vista tanto ideológico, quanto das políticas públicas. Ver, por exemplo: Breneman, Pusser e Turner (2006); Kezar, Chambers e Birkhardt (2005); Ruch (2001); Lyall e Sell, K. (2006); Slaughter e Rhoades (2004); Priest e St. John (2006). Obviamente, é compulsória a leitura do livro sobre o empreendimento que deu origem à enorme polêmica mundial: Sperling (2000).

${ }^{11}$ Ver, a esse respeito, Levy (2002) e Kinser e Levy (2005).

12 O Decreto $n=2.207$, de 15 de abril de 1997, revogado pelo Decreto $n^{2} 2.306 / 1997$, foi o primeiro a dispor sobre a questão (parágrafo único do art. $1^{2}$ ). Porém, apenas com a edição da MP n^1.477-39, que amparou o novo decreto, houve sustentação em norma superior. Essa reedição da MP, cuja origem remonta à $\mathrm{MP} \mathrm{n}^{\circ} 550 / 1994$, que não tratava dessa questão, alterou artigo da Lei n 9.131/1995. Ainda houve reedições até a 67 versão, MP $n^{\circ} 1.890 / 1999$, que, pelo Projeto de Conversão $n 5 / 1999$, transformou-se na Lei $n \_9.870$, de 23 de novembro de 1999, ainda vigente.
} 
da Lei no 9.131/1995 e da LDB de 1996, determinava que as universidades e estabelecimentos isolados, quando particulares, deveriam constituir-se sob a forma de fundações ou associações. ${ }^{13}$

O Cadastro das Entidades Mantenedoras do MEC/Inep registra, em março de 2007, um total de 1.693 entidades públicas e privadas que mantêm IES, havendo predominância das últimas (93\%). A tabela 2 mostra a situação atual das mantenedoras do país, segundo a personalidade jurídica. Constata-se que, 10 anos após os atos legais que explicitaram a possibilidade de mantença de cursos superiores por entidades com fins lucrativos, este grupo já alcança o total de 755 instituições, ou seja, quase a metade do total das mantenedoras privadas - 48\% de 1.572. Cumpre salientar que uma análise histórica da evolução desse processo fica prejudicada pelo modo como os dados estão organizados no cadastro. ${ }^{14}$

\begin{tabular}{|c|c|}
\hline \multicolumn{2}{|c|}{$\begin{array}{c}\text { Tabela } 2 \\
\text { Mantenedores, por personalidade jurídica } \\
\text { (Brasil, 2007) }\end{array}$} \\
\hline Personalidade jurídica & Total \\
\hline Privado - Com fins lucrativos — Associação de utilidade pública & 18 \\
\hline Privado - Com fins lucrativos - Sociedade civil & 441 \\
\hline Privado - Com fins lucrativos - Sociedade mercantil ou comercial & 296 \\
\hline Total privado - com fins lucrativos & 755 \\
\hline Privado — Sem fins lucrativos — Associação de utilidade pública & 210 \\
\hline Privado — Sem fins lucrativos - Fundação & 351 \\
\hline Privado — Sem fins lucrativos — Sociedade & 256 \\
\hline Total privado — sem fins lucrativos & 817 \\
\hline Total de mantenedores privados & 1.572 \\
\hline Público - Estadual & 37 \\
\hline Público - Federal & 18 \\
\hline Público - Municipal & 66 \\
\hline Total de mantenedores públicos & 121 \\
\hline Total de mantenedores & 1.693 \\
\hline
\end{tabular}

${ }^{13}$ Lei $\mathrm{n}^{2} 5.540$, de 28 de novembro de 1968. Ressalte-se, contudo, que decisões do antigo Conselho Federal de Educação, tomadas nos anos 1970, admitiam que entidades que pleiteavam a mantença de cursos superiores estivessem constituídas como sociedades mercantis. Ver, por exemplo, o Parecer CFE $n^{2}$ 1.002/1972.

${ }^{14} \mathrm{O}$ Cadastro das Entidades Mantenedoras, base de dados que não está disponível no site do MEC/Inep, fundamentalmente é um instrumento utilizado para registrar as principais características institucionais das mantenedoras. Não se trata, portanto, de uma base de informações 
O impacto dessa decisão no setor como um todo fica evidente na tabela 3, que registra o crescimento gradativo, porém constante, das matrículas em IES mantidas por entidades privadas com fins lucrativos. Constata-se que, em 2005 , tais entidades já respondiam por $18,7 \%$ dos alunos matriculados em IES e por $25,8 \%$ dos matriculados em instituições privadas. A julgar pelos números apresentados, o crescimento do segmento lucrativo vem se realizando em direção contrária ao das instituições públicas, cuja participação vem se reduzindo progressivamente. Se, em 2000 , o setor público respondia por $32,9 \%$ do alunado, em 2005 essa participação passou para 26,8\%.

\begin{tabular}{|c|c|c|c|c|c|c|}
\hline \multicolumn{7}{|c|}{$\begin{array}{c}\text { Tabela } 3 \\
\text { Matrículas em IES segundo o regime jurídico da mantenedora } \\
\text { (Brasil, 2000-05) }\end{array}$} \\
\hline Discriminação & 2000 & 2001 & 2002 & 2003 & 2004 & 2005 \\
\hline \multicolumn{7}{|l|}{ Total de mantedoras privadas } \\
\hline com fins lucrativos & 324.758 & 396.896 & 506.360 & 630.080 & 725.673 & 831.447 \\
\hline \multicolumn{7}{|l|}{ Total de mantedoras privadas } \\
\hline sem fins lucrativos & 1.433 .058 & 1.639 .501 & 1.873 .483 & 2.084 .269 & 2.226 .688 & 2.394 .385 \\
\hline Total privadas & 1.757 .636 & 2.036 .397 & 2.379 .843 & 2.714 .349 & 2.952 .361 & 3.225 .832 \\
\hline Total públicas & 887.026 & 939.225 & 1.051 .655 & 1.136 .370 & 1.178 .328 & 1.192 .189 \\
\hline Sem informação & 374.161 & 452.928 & 554.775 & 666.383 & 758.717 & 866.582 \\
\hline Total alunos matriculados 2000-05 & 2.694 .245 & 3.030 .754 & 3.479 .913 & 3.887 .022 & 4.163 .733 & 4.453 .156 \\
\hline
\end{tabular}

Apesar de a educação superior ser, como dito anteriormente, um "nãotema", ou, talvez, justamente por ser um "não-assunto", seu crescimento temse dado por meio do setor privado, como se deduz dos números apresentados. Ou seja, uma questão estratégica para o país - a formação de quadros capa-

concebida para pesquisar e analisar a evolução da educação superior. Diferentes dimensões do cadastro contribuem para esse entendimento. Em primeiro lugar, o cadastro é preenchido pelas próprias instituições, o que dá margem a interpretações diversas em relação ao preenchimento de uma mesma informação. Além disso, registre-se que o processo de alimentação da base não é contínuo, podendo haver defasagem nos dados. Por fim, há falta de padronização ou formatação inadequada de alguns campos, como o da data de publicação da criação da mantenedora, onde estão previstos apenas dois dígitos para indicar o ano - não se permitindo, por exemplo, diferenciar uma entidade como a Sociedade Brasileira de Instrução, mantenedora da Universidade Candido Mendes, criada em 1902, de outra mantenedora surgida em 2002. 
zes de garantir a competitividade e o desenvolvimento econômico — vem definindo seus contornos sem que o Brasil tenha deliberado, seja explícita, seja implicitamente, sobre um de seus aspectos fundamentais.

Pode-se argumentar que o crescimento do setor privado ocorreu, inicialmente, como complemento ao desenvolvimento do setor público. Por isso apresentava algumas características específicas: concentrava-se na criação de instituições não-universitárias, cuja estrutura de custos era menor; as IES privadas instalavam-se em regiões onde não havia instituições públicas ou onde sua atuação era insuficiente; eram abertos cursos e vagas para atender a demandas não-cobertas, como a de alunos que não conseguiam passar pelo competitivo processo seletivo das universidades públicas ou que só podiam estudar após o trabalho (turno da noite).

Com a crise econômica e social que predominou na década de 1980, indo até o início dos anos 1990, o crescimento da educação superior foi afetado como um todo. Todavia, ao se manifestar também como uma crise de financiamento do Estado, acabou por ser mais intensa no setor público, o qual, pelo próprio porte de suas instituições universitárias e pelo ativismo de docentes e servidores, tinha gestão mais complexa e onerosa do ponto de vista tanto econômico quanto político. A estabilidade da economia, alcançada em meados dos anos 1990, conjugou-se, assim, com o esgotamento da capacidade de investimento do Estado brasileiro, o que restringiu a expansão da educação superior pela via pública.

Com a promulgação da LDB e a posterior regulamentação, abriam-se as portas para o expressivo crescimento do setor privado. Tal fato não demorou a se confrontar com a matriz de orientação da educação superior que se fundamentava no setor público, em parte pela tradição e força das universidades federais e estaduais, mas também porque o poder público federal é o principal agente de regulação.

O Brasil claramente estimulou, por meios legais e regulamentações, a constituição de um setor educacional com fins lucrativos, fazendo do país um caso desviante das tendências mundiais ainda hoje dominantes. Em geral, em países nos quais existe um denso componente privado, a educação superior com finalidade lucrativa é tolerada, mas não se registram políticas públicas, como a brasileira, de incentivo à mercantilização do setor. A natureza essencialmente privada da educação superior brasileira, independentemente da finalidade lucrativa, já fazia do Brasil, ao lado do Chile, das Filipinas e do Japão, um país diferente dos demais. Entretanto, apenas no Brasil, Chile e Japão as matrículas em universidades representam mais de $50 \%$ do total de estudantes, 
ao contrário, por exemplo, de países como Alemanha, Grécia, Canadá e Austrália, nos quais a educação é quase completamente pública. ${ }^{15}$

Se é um "ponto fora da curva" em termos das estatísticas internacionais comparadas, ${ }^{16}$ outro tema faz do país, tristemente talvez, um caso desviante no que se refere à realidade de suas "universidades". É que universidade, no Brasil, é matéria de lei, não de fundamento acadêmico. É a lei, a LDB, em linha com a Constituição, que define o que é universidade. ${ }^{17}$ No caso, universidade é uma entidade educacional que faz, indissociadamente, pesquisa, ensino e extensão e que, para isso, ou por isso, precisa ter um terço de docentes com título de mestres e doutores, bem como um terço de docentes em regime de tempo integral. Sejamos francos: é muito pouco para qualquer universidade séria no planeta. Em geral, nas universidades verdadeiras, o título de doutor constitui a regra de entrada para a vida acadêmica, bem como a dedicação integral constitui outro corolário da vida universitária regular. O que se pede na lei é absolutamente insuficiente para qualquer universidade que se queira, em termos comparativos, ser considerada como tal. Entretanto, a grande maioria do setor privado brasileiro não conseguiria demonstrar esse mínimo determinado, se lhe fosse requerida a demonstração.

Por outro lado, não se imagina universidade sem programas de doutoramento, nos quais se reproduz e se guarda a trajetória das disciplinas e das ciências. ${ }^{18}$ No Brasil, contudo, talvez por ser matéria de lei, antes que matéria de mérito acadêmico, grande parte das universidades sequer se qualificaria como tal, se instada a mostrar sua orientação disciplinar fundamental, como dissemos, refletida, como de hábito, nos programas de doutoramento. Observemos os números a seguir.

A efetiva integração entre ensino e pesquisa acontece na pós-graduação stricto sensu, não obstante a existência de tais atividades também no âmbito da

\footnotetext{
${ }^{15}$ Ver Tilak (2006).

${ }^{16}$ Como dito anteriormente, as estatísticas internacionais devem ser lidas com certa cautela. Por exemplo, o estudo citado na nota 14 utiliza-se de dados do Prophe. Mesmo assim, os dados disponibilizados pelo Prophe são produzidos pelas redes nacionais de colaboradores do programa, o que, se por um lado garante sua confiabilidade, por outro com freqüência incorpora critérios variados, por conta de realidades nacionais distintas. Por isso, o próprio programa recomenda cautela na utilização de seus dados.

${ }^{17}$ Neste sentido, é útil buscar entender, até mesmo para compreender o que estamos fazendo no Brasil, o papel e o impacto da lei na educação superior e na vida das instituições de ensino superior. Ver, por exemplo, "Higher education law in the the common law systems" e "Higher education law in the civil law systems" em Farrington e Palfreyman (2006).

${ }^{18}$ A esse respeito, ver Golde e Walker (2006).
} 
graduação. Se adotarmos alguns requisitos mínimos para avaliar a oferta de programas de doutorado e mestrado, veremos que a situação do ensino universitário brasileiro é bastante frágil. Em dezembro de 2006, o Brasil tinha um total de 177 universidades, das quais 86 eram privadas, ou seja, pouco menos da metade $(48,6 \%)$.

Considerando, como requisito, a oferta de pelo menos três cursos de mestrado e um de doutorado, constata-se que menos da metade do total de universidades brasileiras (44\%) atende a tal critério. No caso das universidades privadas, apenas três, de cada 10, têm pelo menos três mestrados e doutorados, como mostra a tabela $4 .{ }^{19}$

\begin{tabular}{|c|c|c|c|}
\hline \multirow{3}{*}{ Categoria administrativa } & $\begin{array}{l}\text { Tabel } \\
\text { nos }\end{array}$ & e ur & rado \\
\hline & & & \multirow{2}{*}{ Total } \\
\hline & Não & $\operatorname{Sim}$ & \\
\hline \multirow[t]{2}{*}{ Universidades federais } & 15 & 38 & 53 \\
\hline & $28 \%$ & $72 \%$ & $100 \%$ \\
\hline \multirow[t]{2}{*}{ Universidades estaduais } & 20 & 13 & 33 \\
\hline & $61 \%$ & $39 \%$ & $100 \%$ \\
\hline \multirow[t]{2}{*}{ Universidades municipais } & 4 & 1 & 5 \\
\hline & $80 \%$ & $20 \%$ & $100 \%$ \\
\hline \multirow[t]{2}{*}{ Universidades privadas } & 60 & 26 & 86 \\
\hline & $70 \%$ & $30 \%$ & $100 \%$ \\
\hline \multirow[t]{2}{*}{ Total } & 99 & 78 & 177 \\
\hline & $56 \%$ & $44 \%$ & $100 \%$ \\
\hline
\end{tabular}

Quando se adota um critério mais restritivo, cinco mestrados e dois doutorados, constata-se que, de cada grupo de 10 universidades brasileiras, sete não cumprem o requisito. Apenas no grupo de universidades públicas federais, a parcela que atinge o mínimo necessário é predominante (64\%). Pelo exposto

\footnotetext{
${ }^{19}$ Dados elaborados pelo Observatório Universitário, conjugando informações da Capes, sobre cursos de pós-graduação recomendados e reconhecidos, e do Inep, com o Cadastro das Instituições de Educação Superior. Ver Nogueira (2007).
} 
na tabela 5, comprova-se que a grande dificuldade para a expansão da pósgraduação stricto sensu está na oferta de cursos de doutorado, especialmente no que diz respeito às universidades públicas municipais e às universidades privadas.

\begin{tabular}{|c|c|c|c|}
\hline Universidades co & $\begin{array}{l}\text { Tabel } \\
\text { os cir }\end{array}$ & e do & orado \\
\hline \multirow{2}{*}{ Categoria administrativa } & \multicolumn{2}{|c|}{ Cumprem o requisito? } & \multirow{2}{*}{ Total } \\
\hline & Não & $\operatorname{Sim}$ & \\
\hline \multirow[t]{2}{*}{ Universidades federais } & 19 & 34 & 53 \\
\hline & $36 \%$ & $64 \%$ & $100 \%$ \\
\hline \multirow[t]{2}{*}{ Universidades estaduais } & 24 & 9 & 33 \\
\hline & $73 \%$ & $27 \%$ & $100 \%$ \\
\hline \multirow[t]{2}{*}{ Universidades municipais } & 5 & & 5 \\
\hline & $100 \%$ & & $100 \%$ \\
\hline \multirow[t]{2}{*}{ Universidades privadas } & 74 & 12 & 86 \\
\hline & $86 \%$ & $14 \%$ & $100 \%$ \\
\hline \multirow[t]{2}{*}{ Total } & 122 & 55 & 177 \\
\hline & $69 \%$ & $31 \%$ & $100 \%$ \\
\hline
\end{tabular}

Como se observa, o parque universitário brasileiro como um todo é bastante frágil, até mesmo por sua juventude. Registre-se, contudo, que não existem recursos públicos para a pesquisa no setor privado, ficando este inteiramente dependente do valor de suas mensalidades para financiar o que se requeria, caso a regulação fosse verdadeira e efetiva, para a constituição de uma universidade..$^{20}$ Reside aqui uma das idiossincrasias, senão falsidades, regulatórias brasileiras: o aparato regulatório não distingue explicitamente entre universidade pública e privada, querendo-as, implicitamente, idênticas. Mas não ha-

${ }^{20}$ Observe-se que essa característica é mais uma particularidade brasileira, uma vez que na maioria dos países onde o setor privado é majoritário, recursos públicos são também destinados ao ensino superior privado. Visão comparativa aplicada a países de grandes contingentes de estudantes matriculados em instituições privadas pode ser buscada em Meek e Suwanwela (2006). 
vendo financiamento público para o setor privado, isso jamais acontecerá, como bem sabe todo o planeta. Por outro lado, quer o aparato regulatório que as universidades públicas e as privadas sejam formalmente, do ponto de vista da regra, idênticas. Só que o setor público, por lei, cria universidades, já nascidas como tal, universidades sem qualquer aparato de pesquisa, sem qualquer programa de doutoramento, sem qualquer trajetória histórico-institucional.

Reside aqui outra peculiaridade brasileira. Não só a definição de universidade é matéria de lei, posto que definida pela LDB, a partir de rudimentar regra aritmética de um terço de mestres e doutores e um terço de professores em tempo integral, como também tal regra não se aplica às universidades criadas pelo poder público. Estas, embora sequer tenham base física, nem cursos, nem professores, já nascem universidades, e sob esta nomenclatura, este direito, continuarão a existir, independentemente do que venham a fazer no futuro. ${ }^{21}$

Sejamos sinceros, não há como levar a sério esta confusão normativa, esta parafernália regulatória, que se transforma, e nos transforma a todos, em veículo de banal discussão jurídico-formal, sem nenhum fundamento acadêmico, e infantiliza a política pública brasileira, que, obediente às leis, tem de visualizar regulamentações sobre um objeto inespecífico, mal definido e que varia conforme sua natureza administrativa: se pública a instituição, a ela não se aplica a LDB, até mesmo porque é criada por lei de igual força. Se privada, a ela se aplica a LDB, com seu patamar pueril de definição do que seja uma universidade, patamar esse ao qual dificilmente podem aderir por completo as casas privadas, em função de restrições de receita.

Claro, cabe perguntar: qual política pública estamos a fazer? A que contenha fundamentos sólidos para o futuro, ou a que apenas se contente com a infinita discussão sobre minudências e definições legais irrelevantes? No momento, a resposta é fácil: estamos a tocar a política pública formalista, nada mais.

\footnotetext{
${ }^{21}$ Parece inescapável que o país tenha de corrigir suas normas sobre universidades, a começar pela tosca definição que aparece na LDB, mas não somente por aí. Seria necessário, também, discutir de que maneira concebemos um verdadeiro parque universitário e o que esperamos dele. Atualmente há uma pressão permanente para a criação de novas universidades. De um lado, o Congresso as vê, certamente com alguma razão, como potente instrumento de política regional, e por isso comanda, sem nenhum critério de natureza acadêmica ou, a bem da verdade, sem critério de qualquer natureza, por via de leis, a criação de novas universidades. De outro, o setor privado vê, e com boas razões, na chancela universitária nada mais que a licença para abertura de cursos e aumento de vagas. A tosca versão de universidades inscrita na LDB acabou empobrecendo sobremaneira a inteligência brasileira sobre o significado da verdadeira universidade, fazendo da definição legal um sinônimo, tristemente verdadeiro, de uma moenda de abertura de cursos e aumento de vagas, ou de prestígio político de deputados federais e senadores. Nada a ver, claro, com a educação superior universitária propriamente dita.
} 
Por isso, nosso aparato regulatório é minudente, detalhado, requer múltiplas especificações sobre PDIs, PPIs, projetos pedagógicos, CPAs, número de livros, acessos para cadeiras de rodas, número de alunos por turma, número de alunos por turma de prática, número de cabines para estudo individual, coisas assim. Certamente um aparato defensivo, destinado a requerer do setor privado o cumprimento aritmético disso ou daquilo. Apenas defensivo, julgando que a minudência destina-se a impedir que o regulador seja logrado por artimanhas do regulado. Regulação defensiva é certamente regulação primitiva, deixando de tirar vantagens estratégicas da função, deixando de apontar qual futuro deseja perseguir. Neste sentido, no Brasil regula-se o passado, a experiência conhecida, deixando o futuro sob o comando do passado.

\section{Diversificação da educação superior: inovações e permanências}

A LDB de 1996 dispôs que a educação superior deveria ser ministrada em instituições com variados graus de abrangência ou especialização, sejam elas públicas ou privadas. Até a LDB, as IES podiam ser divididas em dois tipos básicos: instituições universitárias (universidades) e instituições não-universitárias (estabelecimentos integrados ou isolados, como faculdades, escolas e institutos). O setor privado predominava entre os últimos, o público entre os primeiros. Com a regulamentação da nova LDB, surgiu um novo tipo de instituição universitária: os centros universitários. ${ }^{22}$ Posteriormente, houve a classificação dos centros federais de educação tecnológica (Cefets) no mesmo nível dos centros universitários. ${ }^{23}$

A Constituição de 1988 havia determinado que as universidades gozariam de autonomia didático-centífica, administrativa e de gestão financeira e patrimonial e deveriam obedecer ao princípio da indissociabilidade entre ensino, pesquisa e extensão (art. 207). Já a LDB, ao categorizar as universidades, dispôs que são instituições pluridisciplinares de formação dos quadros profissionais de nível superior, de pesquisa, de extensão e de domínio e cultivo do saber humano. E mais, que deveriam atender a três requisitos: um terço do corpo docente com titulação acadêmica de mestrado ou doutorado; igual percentual enquadrado em regime de tempo integral; produção intelectual institucionalizada (art. 52, incisos I a III).

${ }^{22}$ Decreto $\mathrm{n}-2.207$, de 15 de abril de 1997, sucedido pelos Decretos $n=2.360 / 1997,3.860$ /

2001 e 5.773/2006 (este em vigor), que mantiveram a disposição sobre o assunto.

${ }^{23}$ Decreto n 5.225 , de 1 - de outubro de 2004. 
Diante dessas determinações legais, constata-se que as universidades estão submetidas a fortes condicionantes - por exemplo, oferta de programas de pós-graduação stricto sensu - que lhes impõem uma estrutura mais onerosa, tendo como contrapartida algumas prerrogativas - além da abertura de cursos e campus em sua sede, a possibilidade de expansão para fora da sede, desde que no mesmo estado. Já os centros universitários e os Cefets, embora tendo menos prerrogativas, podem abrir cursos e vagas no município-sede, sem estar submetidos aos custos maiores das universidades.

Como conseqüência desse quadro, boa parte da expansão recente da educação superior ocorreu em instituições universitárias que não são universidades. Em 1999, primeiro ano em que se registrou sua presença, os centros universitários somavam 34 instituições. Em 2005, já havia 114, 192\% a mais. No período, as matrículas passaram de 160.977 a 674.927 , um incremento de $319 \%$. No mesmo período, os centros federais de educação tecnológica tiveram um crescimento de $1.050 \%$ no número de instituições (de 16 a 184) e de $327 \%$ nas matrículas (de 19.484 a 83.219). Para efeitos comparativos, as universidades aumentaram seu total em $14 \%$ e suas matrículas em $52 \%$.

Não obstante o que dispõe a taxionomia institucional, não poucas vezes ocorre pequena diferenciação entre os tipos de instituições universitárias. Isso pode ser empiricamente constatado comparando-se, por exemplo, dados quanto à oferta de cursos, ao perfil do alunado, aos resultados de processos avaliativos. Na prática, tal similaridade faz com que ocorra uma competição pela obtenção de recursos entre IES classificadas em categorias diferentes. Assim, as normas educacionais, ademais da imposição de custos diferenciados, pouco afetam a desejável reestruturação do sistema nacional de educação superior, notadamente quanto à diversificação institucional que decorre de vocações, missões e metas específicas, as quais deveriam estar associadas ao contexto em que as IES se encontram.

A LDB de 1996 também procurou flexibilizar a educação superior, possibilitando a oferta de uma formação diferenciada. Além dos cursos de graduação, pós-graduação e extensão, criou-se uma nova modalidade de ensino superior, os cursos seqüenciais. Concebidos para a oferta de educação superior de curta duração, os seqüenciais, por não serem considerados cursos de graduação, têm encontrado resistências para seu desenvolvimento.

No processo de regulamentação da LDB, foram também criados os cursos superiores de tecnologia, que são cursos de graduação que conferem o diploma de tecnólogo, tendo duração menor do que a graduação tradicional 
(bacharelado e licenciatura). Os cursos de graduação tecnológica, apesar de atraírem um grande contingente de estudantes, também encontraram resistências, dessa vez da parte das corporações profissionais, que passaram a defender que apenas os bacharelados possibilitam o registro em profissões regulamentadas.

Formatos alternativos à graduação tradicional existem com sucesso em vários países do mundo. Geralmente servem para diferenciar da formação acadêmica robusta - que conduz, por exemplo, a carreiras acadêmicas e científicas - uma formação pós-secundária voltada para a inserção do estudante no mercado de trabalho. Boa parte do aumento das taxas de escolarização no plano internacional decorre desses tipos de cursos que visam atender a um perfil específico de alunos.

No Brasil, os cursos superiores de tecnologia têm respondido por parcela da expansão, apesar das restrições das corporações profissionais, bem como das universidades federais que não os oferecem. Observe-se que o alunado que demanda tal curso origina-se de segmentos menos favorecidos da população. Dada sua natureza inovadora e porque em grande medida respondem a demandas locais específicas e por vezes provisórias, tais cursos também encontram dificuldades ao lidar com os órgãos de regulação do governo, que buscam uniformizar seus formatos seguindo diretrizes nacionais.

A propósito, cumpre salientar que problema similar acontece em relação às diretrizes curriculares da graduação. Concebidas para flexibilizar a educação superior, em substituição à rigidez dos currículos mínimos, acabaram por sofrer as mesmas pressões por padronização via ótica de profissionalização do ensino, especialmente para atender a demandas oriundas das corporações de profissões regulamentadas. Assim, cursos com projetos pedagógicos inovadores, uma necessidade educacional dada a complexidade do mundo contemporâneo, encontram grande dificuldade no processo de sua regularização.

Em suma, a dificuldade do governo - e também de segmentos da sociedade interessados na educação superior - em lidar com o duplo processo de expansão acelerada da educação superior e de diversificação de instituições e cursos tem causado um excesso de regulações normativas, não poucas vezes contraditórias entre si e com o desenvolvimento pretérito. Como se não bastasse estar na contramão do espírito inovador e flexibilizador da LDB, a sobrecarga regulatória prejudica a formação e o desenvolvimento do capital humano nacional - seja da elite, seja dos setores socioeconômicos menos favorecidos - , bem como atrapalha o próprio espírito da educação permanente. 


\section{Educação superior: profissionalização precoce e conteúdos impertinentes}

A educação superior insere-se em um processo continuado de aprendizagem, não devendo representar tão-só um ponto final. Eventualmente, um estudante graduado pode seguir logo à fase de pós-graduação, ingressando em carreira acadêmica ou científica, na qual o estudo permanente faça parte de suas atividades profissionais. Mas também é plenamente possível que, tendo ingressado no mercado de trabalho, um profissional resolva passar por processo de reciclagem, acorrendo a uma IES ou mesmo no contexto da educação corporativa.

No processo de ensino e aprendizagem, é crucial saber quantificar o volume de trabalho discente, qualificar o conteúdo que se quer apreendido, de forma satisfatória, pelo estudante. Considerando-se a formação acadêmica e profissional como um processo continuado, torna-se evidente que a educação pós-secundária não se resume ao ensino de graduação. Por isso, inexiste um volume, por assim dizer fechado como um pacote, que seja por si só satisfatório para se atestar o aprendizado. Até porque um estudante da educação superior não está ali apenas para ser ensinado, deve também ter iniciativa no processo de sua própria aprendizagem. Não obstante, é preciso registrar que a ênfase dada à mensuração do conteúdo acadêmico como sendo uma soma de atividades em sala de aula encobre um dos grandes problemas da educação superior brasileira: o baixo volume de trabalho discente não poucas vezes associado a conteúdos defasados ou desnecessários.

A educação superior, em suas diferentes áreas de atuação (cursos seqüenciais, tecnológicos, graduação tradicional, pós-graduação lato e stricto sensu), pode se direcionar tanto à formação de elites, como em seus primórdios, quanto ao cultivo da cultura e do conhecimento dos cidadãos médios do país. Igualmente, pode-se voltar tanto à preparação de recursos humanos funcionais para o mercado de trabalho quanto à qualificação de pessoal dedicado às carreiras acadêmicas e científicas, o qual virá a assegurar a continuidade da própria educação superior.

Além de tudo que já foi destacado, não se pode deixar de comentar a contradição presente no modelo de educação superior brasileiro, o qual se coloca, claramente, na contramão das exigências de um mercado de trabalho moderno, complexo e rotativo. No Brasil, o diploma universitário em geral dá acesso a uma profissão. ${ }^{24}$ Desde o ensino médio os estudantes brasileiros são

${ }^{24}$ O tema da profissionalização precoce e da configuração dos cursos de graduação, não apenas
em consonância com o que se observa em outros países, mas também no sentido de melhor 
orientados a escolher uma profissão. Esse formato se baseou no modelo franco-ibérico, que, por sustentar um ensino médio academicamente rigoroso e humanista, considera seus estudantes aptos a ingressar no mundo profissional após a conclusão dos cursos superiores. É, no entanto, completamente diferente da matriz de ensino norte-americana, que se baseia na lógica da formação continuada.

Tem-se, assim, uma espécie de ciclo perverso subjacente à formação dos estudantes brasileiros, que tem sua visão de mundo simplificada e que, como dissemos, está na contramão justamente do mundo profissional, em contradição com o próprio mercado de trabalho..$^{25}$ Apesar de o contingente de pessoas com formação superior disponível para o mercado de trabalho ser bastante reduzido, aproximadamente 6\% da população com 23 anos ou mais de idade tem educação formal de nível superior, é interessante observar como se dá o diálogo entre o mundo da educação e o mundo do trabalho no Brasil.

Em primeiro lugar, registre-se que o Cadastro Brasileiro de Ocupações (CBO) ${ }^{26}$ utilizado pelo IBGE no levantamento e classificação das informações relativas ao mercado de trabalho, contabiliza a existência de 2.422 ocupações. Já o Censo da Educação Superior, de 2004, apresenta 485 diferentes denominações para um total de 18.644 cursos de graduação, aí incluídos as licenciaturas e os tecnológicos. Observa-se, portanto, o grande número de ocupações, ou de denominações de ocupações representadas pelos cursos, existentes no país vis-à-vis o baixo número de profissões regulamentadas. Isso indica o quanto o mercado de trabalho é complexo, dinâmico e diferenciado e o quanto a economia moderna, apesar da crescente importância do conhecimento especializado na sociedade contemporânea, não se restringe às ocupações regulamentadas, ou seja, às profissões.

Além disso, dados do Censo Demográfico de 2000 demonstram que 54\% das pessoas ocupadas, formadas nas áreas com maior número de alunos de graduação, exerciam trabalhos diversos, não necessariamente corresponden-

atender à crescente demanda por uma formação fora dos padrões profissionais-corporativos, tem sido amplamente discutido nos trabalhos do Observatório Universitário, disponíveis em $<$ www.observatoriouniversitario.org.br > . Ver, também, Nunes, Nogueira e Molhano (2000).

${ }^{25}$ Essa questão leva a uma reflexão sobre a necessidade de existir uma educação superior funcionalmente diferenciada e/ou especializada, que permitiria, por meio de um processo permanente de educação, várias opções complementares de formação. A esse respeito, ver Nunes et al. (2000).

${ }^{26}$ A Classificação Brasileira de Ocupações (CBO) é o documento normalizador do reconhecimento, da nomeação e da codificação dos títulos e conteúdos das ocupações do mercado de trabalho brasileiro. É ao mesmo tempo uma classificação enumerativa e uma classificação descritiva. 
tes às áreas em que se formaram. Apenas pouco mais da metade das pessoas formadas em direito, curso com forte viés profissionalizante, exercia ocupações na área de formação. Proporção semelhante registra-se em relação aos formados em pedagogia e letras, respectivamente $56 \%$ e $55 \%$. Chama a atenção também o fato de que dois terços dos formados nas engenharias não trabalhavam na área correspondente ao título superior. A exceção são os formados em medicina, ${ }^{27}$ dos quais $75 \%$ trabalhavam na área correspondente à formação. Ou seja, há um grande contingente de pessoas com curso superior que não trabalha na área em que se formou, com exceção daquelas que fizeram medicina, setor altamente profissionalizado. ${ }^{28}$

\section{Figura 3}

Percentagem de pessoas de 23 anos ou mais trabalhando em área correspondente à de formação (Brasil, 2000)

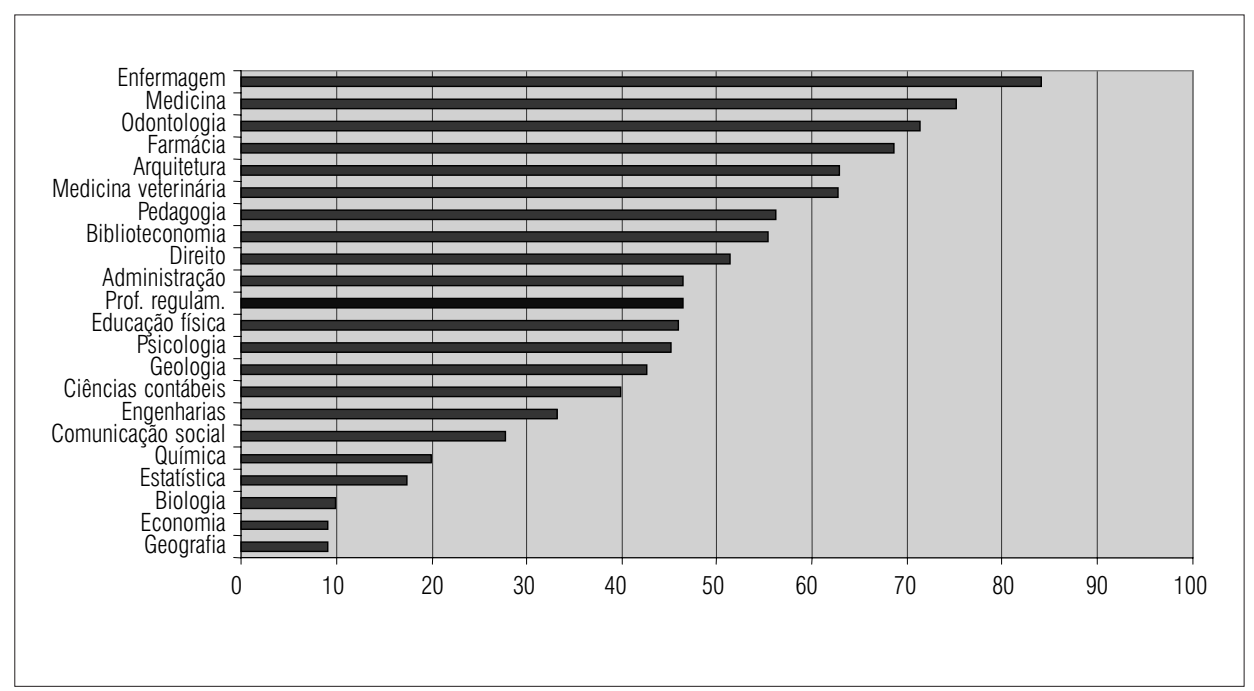

Se a observação da empregabilidade dos formados já revela uma baixa relação entre formação e profissão (exceção sempre feita à medicina), o qua-

\footnotetext{
${ }^{27}$ Medicina foi incluída, apesar de não integrar o grupo dos cursos de graduação com maior número de alunos, por ser uma das chamadas profissões imperiais e, principalmente, por ser a que apresenta a maior taxa de aderência entre formação e ocupação.

${ }^{28}$ Ver a esse respeito, Nunes e Carvalho (2007).
} 
dro de diversidade no mercado de trabalho é reforçado quando a análise se detém na configuração das ocupações no Brasil, ou seja, a análise da formação das pessoas dentro das ocupações. Exemplo nesse sentido pode ser encontrado na elite dirigente tanto do setor público quanto do setor privado brasileiro.

Nesse recorte ocupacional, constata-se, em relação aos dirigentes do setor público - dirigentes gerais, dirigentes de produção e operações e dirigentes das áreas de apoio - , que expressiva parcela do contingente de pessoas que exercem tais ocupações não tem curso superior: respectivamente $68 \%, 71 \%$ e $57 \%$. No âmbito privado, e ainda em relação à elite dirigente, a situação não é muito diferente: $73 \%$ dos dirigentes de empresas e empregadores não possuem instrução superior completa. Em suma, sete de cada 10 integrantes da elite gestora do Estado brasileiro não têm a educação que hoje seria considerada mínima para assumir postos vitais. Trata-se de um número drástico que dispensa comentários, como toda boa tragédia.

Registre-se também que, conforme o Censo da Educação Superior de 2004, mais da metade dos egressos (57\%) de nossa educação superior está associada às profissões regulamentadas, para as quais existem corporações ativas, embora isso tenha diminuto significado na vida real do trabalho, na vida depois que se sai da universidade.

Primeiro, porque no topo do mercado de trabalho ainda tem pouco significado o volume de educação profissional, dado que o estoque de dirigentes brasileiros ainda é constituído, majoritariamente, por pessoas que não estiveram na educação superior.

Segundo, porque existe uma baixa relação entre a área na qual o estudante se forma e sua atividade profissional efetiva. De acordo com os dados do Censo Demográfico 2000, entre o meio milhão de pedagogos existentes no Brasil, e que trabalhavam de forma remunerada na semana de referência do censo, apenas 36\% trabalhavam na área em que se formaram; dos 366 mil formados em letras, tal contingente representava apenas 38\%; em comunicação social, um grupo tão contundente, por exemplo, na defesa do diploma de jornalista, descobrimos que apenas $21 \%$ trabalhavam na área; e em direito, a parcela chegava a apenas 39\%. Como área diferenciada, estava a da saúde, na qual medicina apresenta uma participação das pessoas trabalhando no mesmo segmento profissional de sua graduação muito mais intensa do que as anteriormente mencionadas.

Se assim é, precisamos aprender, ou melhor, concluir que as profissões regulamentadas, que tanto poder têm diante do MEC e do sistema político, e que tantos alunos atraem, até servem para formar quadros para elas mesmas, as profissões regulamentadas. Até servem, mas não deveriam constituir a função primordial ou destinação principal da educação superior brasileira dos dias atu- 
ais. E, justamente, cabe ao sistema nacional de educação superior, por meio de suas instituições e cursos, responder aos desafios que tais questões suscitam.

Mesmo depois que a LDB aumentou o calendário escolar anual de 180 para 200 dias, uma realidade permanece: os alunos da educação superior brasileira ainda estudam pouco. Por quantidade de estudo entenda-se o volume de trabalho necessário para que o estudante se forme, incluindo tanto as atividades presenciais em classe - sala de aula, laboratórios etc. — quanto as nãopresenciais - como horas despendidas em biblioteca ou mesmo em casa.

Dados do antigo Exame Nacional de Cursos (Provão) de 2003 mostravam que $60 \%$ dos estudantes freqüentavam cursos noturnos, caracterizados pela menor carga de trabalho discente. Nesse turno, a hora-aula adotada, por exemplo, costuma ser de 45 minutos ou mesmo de 40 minutos - inferior à predominante no diurno (50 minutos) - e raramente a carga horária semanal excede 20 horas. Considerando o calendário escolar de 200 dias úteis, tomando por premissa que haja cinco dias letivos por semana, são 40 semanas úteis anuais. Ora, ainda que houvesse carga horária diária de 4 horas, isto é, 20 horas semanais, o total despendido em atividades presenciais só atingiria 800 horas/ano. Como parcela considerável dos alunos de cursos noturnos também trabalha (cerca de dois terços), o tempo disponível para atividades nãopresenciais de estudo é reduzido, acrescentando pouco volume de trabalho àquele total anual.

Para efeitos comparativos, pode-se tomar como referência o sistema europeu de transferência de créditos, o ECTS. ${ }^{29} \mathrm{Tal}$ sistema aponta para uma carga média de trabalho discente de 1.700 horas no ano letivo. Cumpre registrar que o volume de trabalho do ECTS refere-se a aulas, trabalhos práticos, seminários, trabalhos de campo, trabalhos pessoais na biblioteca ou no domicílio, entre outros, ou seja, à soma de atividades presenciais em classe e nãopresenciais. Nos Estados Unidos, a carga de trabalho não é menor, exceto na night school ou nas community colleges. Não surpreende, portanto, que no Provão de 2003 mais da metade dos formandos (55\%), independentemente do turno, tenha declarado que os cursos de graduação deveriam ter exigido mais deles.

\footnotetext{
${ }^{29}$ O ECTS (European Credit Transfer and Accumulation System) é uma medida do volume de trabalho para o reconhecimento acadêmico dos cursos realizados em instituições de ensino superior que pertençam aos Estados-membros da União Européia ou aos países que fazem parte do Espaço Econômico Europeu, possibilitando a mobilidade de estudantes entre as instituições de ensino européias sem maiores obstáculos. Ver Magalhães, Nunes e Barroso (2005) e Nunes, Nogueira e Molhano (2003). Sobre o desdobramento e os impactos do "processo de Bolonha" na constituição de uma verdadeira dimensão européia de educação superior, ver a coletânea organizada por Maassen e Olsen (2007).
} 
Registre-se que não há demérito na oferta de cursos superiores de curta duração. Aliás, eles predominam em boa parte dos países, contribuindo inclusive para melhorar as taxas de escolarização superior. O problema está em se oferecer cursos de graduação, com diploma de bacharelado e perfil profissionalizante, os quais, pelo volume de trabalho discente e pelos seus custos financeiros, mais se aproximam de community colleges perdulários.

\section{Economia política, arena política: um setor novo em ação}

Do ponto de vista econômico, o setor educacional tem um porte significativo, representando um dos segmentos mais importantes do país, seja quanto à receita, seja quanto à geração de empregos. Se considerarmos apenas a educação superior, e contabilizando as rubricas receitas próprias, transferências e outras receitas, ${ }^{30}$ a receita bruta total somava, em 2004, $\mathrm{R} \$ 35,483$ bilhões, sendo $\mathrm{R} \$ 19,132$ bilhões gerados pelo setor privado e $\mathrm{R} \$ 16,351$ bilhões pelo setor público.

Para propósitos comparativos, vejamos a receita bruta de vendas ou serviços de algumas empresas relevantes no contexto nacional. ${ }^{31}$ A maior empresa do Brasil, Petrobras, gerou, em 2004, uma receita bruta de $\mathrm{R} \$ 150,403$ bilhões, pouco mais de 4,2 vezes o total do segmento da educação superior. Outra empresa importante no país, a Vale do Rio Doce, teve receita bruta de $\mathrm{R} \$ 29,019$ bilhões, inferior à soma dos setores públicos e privados. A maior empresa do país do setor de bebidas, Ambev, e a maior empresa nacional no setor de telecomunicações, Telemar, geraram, em 2004, receitas brutas de R $\$$ 23,297 bilhões e de R $\$ 22,124$ bilhões, respectivamente.

Tomando-se como parâmetro outra dimensão, a do capital humano ocupado na produção de conhecimento e na prestação dos serviços educacionais, é também relevante o desempenho da educação superior. Em 2004, a massa salarial média mensal da educação superior (grupo 803) movimentou R 943 milhões, situando-se próximo a grupos importantes da economia nacional, conforme tipologia da CNAE. ${ }^{32}$ Para efeito de comparação, o grupo 652, "intermediação monetária, depósitos à vista", somava $\mathrm{R} \$ 1,481$ bilhão de massa

\footnotetext{
${ }^{30}$ MEC/Inep, Microdados do censo da educação superior, 2004.

${ }^{31}$ Bovespa, Balanço das empresas.

${ }^{32}$ A Classificação Nacional de Atividades Econômicas (CNAE) é o instrumento de padronização dos códigos de atividade econômica e dos critérios de enquadramento utilizados pelos diversos órgãos da administração tributária do país.
} 
salarial média mensal e o grupo 851, "atividades de atenção à saúde", $\mathrm{R} \$ 1,183$ bilhão.

No ano de 2004, havia um total de 553.944 profissionais empregados na educação superior, dos quais 293.302 eram docentes e 260.642 técnicos administrativos. ${ }^{33}$ Cumpre destacar também que seis de cada 10 profissionais estavam empregados em IES privadas, as quais eram responsáveis por cerca de dois terços de todos os docentes da educação superior.

Outro dado significativo é o fato de que o rendimento médio dos trabalhadores formais na educação superior, sejam eles docentes ou técnicos administrativos, chegava a $\mathrm{R} \$ 2.294,28$. Tal valor representava duas vezes o rendimento médio de todos os trabalhadores formais ocupados nos 223 grupos de atividades econômicas da CNAE, situando o setor na 35a posição. Conforme informações extraídas da CNAE e da Rais, ${ }^{34}$ a educação superior situava-se entre os 20 maiores empregadores e entre os 10 maiores geradores de massa salarial.

Dados o porte econômico e a relevância social adquirida pela educação superior, não é de surpreender que tenha se tornado uma importante arena de disputa por poder. Aos agentes principais, os mantenedores públicos (governos federal, estaduais e municipais), docentes e técnicos administrativos, com suas associações e sindicatos representativos, vêm se juntar outros grupos como as corporações profissionais e mesmo os poderes públicos Executivo, Legislativo e Judiciário, especialmente o primeiro no exercício das funções de regulação, avaliação e supervisão. ${ }^{35}$

A dimensão e a complexidade da educação superior no Brasil, entendida aqui como o conjunto de instituições de educação superior, os órgãos governamentais, os corpos docente e discente, seus representantes sindicais, patronais e de empregados, o aparato jurídico que os sustenta, as entidades de representação profissional que participam ativamente da política do setor, a relevante representação política através de muitos deputados federais

\footnotetext{
${ }^{33}$ MEC/Inep, Sinopse da Educação Superior.

${ }^{34}$ Sob a responsabilidade do Ministério do Trabalho e Emprego, Relação Anual de Informações

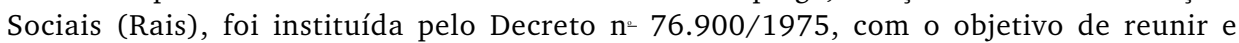
disponibilizar informações sobre o mercado de trabalho.

${ }^{35}$ Neste sentido, a Sesu, a despeito de seu nome - Secretaria de Educação Superior —, se transformou, sem notar talvez, numa secretaria que trata de assuntos econômicos relevantes, enquanto se ocupa, quase exclusivamente, de funções de articulação de interesses representativos, tais como os das entidades profissionais, sindicatos, corporações de ofícios, mantenedores, grupos de interesses variados, inclusive de suas próprias mantidas, as Ifes. Seu tempo é mais gasto com isso do que com questões propriamente educacionais. Num certo sentido, a Sesu já mudou de função substantiva; poderia muito bem incentivar, portanto, a discussão sobre novos modelos regulatórios mais apropriados para esta nova realidade objetiva.
} 
e senadores, fundamenta a sua análise como uma verdadeira arena de políticas públicas. ${ }^{36}$ Porém, antes de se discutir os atributos ou características dessa arena política - até porque alguns já foram abordados ao longo deste artigo -, importa registrar um aspecto bastante peculiar desse universo: a interação dos atores relevantes e, mais especificamente, das entidades representativas e dos órgãos de governo.

Considerando-se que, em tese, os atores normalmente agem estrategicamente, procurando maximizar seus interesses, é no mínimo curioso observar a ausência de uma visão estratégica em relação à educação superior e certo distanciamento das entidades representativas do setor em relação tanto aos órgãos de governo quanto às políticas afeitas à regulação do setor. De uma maneira geral, as entidades representativas do setor deixam transparecer, em suas manifestações públicas e através de sua atuação — ou da não-atuação —, certa ausência de proposições para a educação superior. Isso parece sugerir que atribuem ao Estado a tarefa de pensar e agir estrategicamente.

Projetos estratégicos, com foco mais abrangente, para o desenvolvimento do setor educacional raramente vêm ao debate público. Da parte dos mantenedores privados, as ações são majoritariamente reativas, até no que se refere à extração de benefícios econômicos. Questões pedagógicas e educacionais em sentido mais amplo são quase não-assuntos. É difícil lembrar manifestações concretas de suas entidades representativas que apontem para a importância da educação superior como parte crucial de um projeto de desenvolvimento nacional.

Se destacarmos outro grupo relevante - o dos docentes - , constatamos que basicamente se dedicam às questões trabalhistas e às inerentes às suas respectivas carreiras, ficando em segundo plano os aspectos educacionais. Já as corporações querem fazer de suas necessidades profissionais específicas uma questão educacional, o que se torna ainda mais complicado porque as partes somadas não chegam a um todo coerente.

Por sua vez, os governos (atual e anteriores) identificaram a importância de se desenvolver a educação superior, mas não conseguem lidar com o tamanho e a complexidade hoje existente. Entre as conseqüências disso, ora vem um excesso de regulamentações e controle, ora uma fragilidade nas ações efetivas de supervisão do setor, ou seja, uma fragilidade em conseguir fazer cumprir o que propuseram.

${ }^{36}$ No sentido definido por Lowi (1964). 


\section{Dilemas estratégicos da administração pública}

A Constituição Federal de 1988, à semelhança das que a antecederam, escolheu o mercado como forma possível de expansão da educação superior ao estabelecer que o "ensino é livre à iniciativa privada", desde que atenda às normas gerais da educação nacional e desde que seja autorizado e avaliado pelo Poder Público. Na verdade, desde a Constituição de 1937 o preceito de que a educação é livre à iniciativa vem sendo repetido nas Cartas brasileiras. A rigor, portanto, foi a Constituição - e não os planos de reforma do Estado - que plasmou a natureza eventualmente privatizante da educação superior brasileira.

Ainda que não se possa apontar o momento preciso em que se deu a decisão de expandir o terceiro grau preponderantemente através do setor privado, a evidência empírica, como destacada, aponta para a materialidade de tal decisão. Não apenas os dados sobre o crescimento dos alunos matriculados em IES privadas, como também os números relativos aos gastos da União, apontam para certa estabilidade do gasto com a educação superior. Além disso, como percentagem do PIB, em comparação com outros países, o Brasil apresenta um dispêndio proporcionalmente satisfatório, sendo que, desafortunadamente, o custo médio por estudante do ensino superior, como proporção do PIB per capita, é muito mais alto no Brasil do que na vasta maioria dos países do mundo (Ipea, 2006). Sem prejuízo, até mesmo porque este custo por aluno é alvo de muita discordância, embora a percentagem do PIB brasileiro seja proporcionalmente satisfatória em termos comparativos, quando se estima o PIB per capita por estudante brasileiro, o país fica muito atrás das nações desenvolvidas.

Sabendo-se que orçamentos são animais resistentes à sua reestruturação interna e observando-se o orçamento brasileiro ao longo de décadas, admitese que dificilmente as proporções gastas com educação, principalmente a superior, possam conhecer alteração de magnitude substantiva no futuro, cláusula esta que exigirá, por certo, difíceis decisões alocativas.

Discute-se no momento tanto a reforma universitária, quanto o estabelecimento de um sistema brasileiro de educação superior e a propositura de um marco regulatório para o setor. Estão engajados neste debate o Executivo, o Legislativo e a sociedade. Submeto que é fundamental que se aceite a premissa de que a opção pelo mercado transformou-se em escolha permanente, de modo a melhor formular argumentos conducentes a um marco regulatório. A despeito das dificuldades simbólicas, talvez ideológicas, da adoção explícita de tal perspectiva, até mesmo por suas implicações estratégicas e internacionais - tendo em vista a discussão sobre a educação como um serviço de merca- 
do internacional —, creio ser incontornável tal admissão, de modo a afastar a peneira com a qual vimos cobrindo a luz do sol.

E quais as conseqüências disso?

Sem dúvida, será preciso definir um novo marco regulatório legal para a educação superior, tal como se fez, ainda que de forma fragmentada, para outros setores da economia. A distinção essencial, contudo, é que, à diferença das áreas privatizadas, a educação não é uma concessão pública, exatamente por ser livre à iniciativa privada. Tal marco regulatório que se votará - visto que deve ser lei - precisará contemplar também a regulação da competição por via de órgãos típicos da área econômica, de modo a proteger as instituições da competição predatória, de eventuais dumpings, e incentivar a competição por eficiência, qualidade e preço, bem como viabilizar, o que parece inevitável no futuro, a fusão e absorção de umas instituições pelas outras, assim como a possível existência de firmas educacionais de escopo nacional.

$\mathrm{Na}$ esteira das decisões pregressas que incentivaram, por leis e decretos, a constituição de um setor educacional de natureza empresarial, precisarão ser revistas, por incongruência substantiva com as decisões de apoio ao setor empresarial, as bases da chamada "lei do calote", ${ }^{37}$ que imputa custos extramercado às entidades que, cada vez mais, são de natureza puramente mercantil, fazendo com que tal lei constitua, ela mesma, uma contradição lógica à natureza deste enorme setor econômico, criado ao abrigo do incentivo de políticas públicas. Entende-se, historicamente, que o controle das mensalidades escolares tenha constituído no passado - já um tanto remoto - pauta da política pública, talvez movida por certa consciência culpada do governo por não poder ofertar educação pública para todos. Mas uma vez deliberada a opção pelo mercado, faz pouco sentido que este seja parametrizado por meio de regras como as da chamada "lei do calote". Atualmente, em termos de política pública, somos a favor do mercado, mas não muito. Goste-se ou não deste argumento, ele certamente merece reflexão para que se elucide a lógica que justifica uma ação de incentivo ao mercado somada a uma lógica que lhe tire a natureza competitiva.

Talvez esteja na hora de se imaginar um modelo regulatório totalmente novo, a partir da experiência das agências regulatórias, que poderia consti-

\footnotetext{
${ }^{37}$ Desde janeiro de 1991, quando promulgada a Lei $\mathrm{n}^{\bullet} 8.170$, a legislação que dispõe sobre o valor das anuidades escolares proíbe, expressamente, qualquer penalidade administrativa e/ou pedagógica ao aluno inadimplente. A legislação atual, Lei $\mathrm{n}^{2} 9.870 / 1999$, alterada pela MP n= 2.173-24, de 23 de agosto de 2001, reitera o princípio e estabelece que o aluno inadimplente só pode ser desligado da instituição ao final do período letivo.
} 
tuir, muito bem, uma inspiração para a regulação deste novo setor econômico que está sendo incentivado pelo governo brasileiro. Como natural decorrência de uma regulação de mercado, será preciso fortalecer o sistema de avaliação das IES, inclusive por departamentos da área econômica de governo, de modo a contemplar dimensões relativas a custos, qualidade, direitos, deveres e compromissos.

Ao lado desta veia de mercado, cuja consolidação vai se mostrando inexorável, será fundamental que se preste maior atenção ao sistema público de educação superior, como referência de ensino e pesquisa, visto que é simplesmente impossível garantir a viabilidade e a plausibilidade da escolha de expansão via setor privado se não se estabelecer um marco de referência robusto, cuja constituição depende exclusivamente do setor público, como obrigação irrecusável e imperativa.

No que se refere ao setor público, dadas as restrições e inércias orçamentárias, será inevitável, em algum tempo futuro, decidir sobre o fluxo e a repartição do volume de financiamento do setor público universitário, permitindo-se a existência de diversificação do sistema e admitindo-se o financiamento competitivo, intensivo e diferenciado das IES públicas através de mérito e qualidade, o que resultará em quebra de vários princípios de isonomia e isomorfismo hoje existentes. A rigor, sem se quebrar os princípios da isonomia jurídico-formal entre as instituições federais de ensino superior, as Ifes, não será possível instituir e fomentar uma política de excelência que resulte na institucionalização futura de algumas universidades de classe mundial sob a égide do governo brasileiro.

Por isso mesmo, a admissão de que a empreitada da educação superior é também uma questão de mercado, com suas pertinentes conseqüências regulatórias sobre o setor privado, exigirá, em contrapartida, que se preste atenção estratégica ao setor público universitário. É que o mercado é mau alocador de prioridades e de valores imateriais e intangíveis, movendo-se em função de custos e oportunidades de ganho. Sendo o mercado educacional mau alocador de prioridades estratégicas e valores, não se deve esperar que responda adequadamente à estruturação de um sistema de ensino e pesquisa superior de exemplar qualidade, que venha a servir de referência nacional, tanto pelos enormes custos envolvidos, quanto pela lógica mesma da competição por estudantes, recursos e resultados materiais e financeiros.

Se o país decidir optar - e creio que precisa fazê-lo — por estabelecer padrões de excelência acadêmica, de qualidade internacional a partir de universidades públicas, precisará admitir que a referência acadêmica no Brasil terá de ser matéria de Estado, não de mercado, por ser, em última instância, 
uma questão da sociedade. ${ }^{38}$ No momento, a discussão, encobrindo o sol com a peneira, não permite vislumbrar claramente os desafios e oportunidades trazidos pela decisão passada de expandir o ensino superior via setor privado.

Ignorar as necessidades, a reforma, a diversificação, a diferenciação e o adequado financiamento do setor público de educação superior será indesculpável, senão criminoso, no tempo e deixará o país à míngua de um sistema referencial de excelência acadêmica e de qualidade de ensino.

\section{Sob a forma de conclusão: passados consagrados, futuros alternativos}

\section{Passados consagrados}

Destacamos no artigo, independentemente da ordem, as seguintes características do ensino superior brasileiro:

、 há um crescimento por meio do setor privado;

- como conseqüência desse crescimento, constitui-se uma economia política da educação superior, bem como surge uma arena política nova, no amplo campo das lutas de interesses que caracterizam o país;

\footnotetext{
${ }^{38} \mathrm{~A}$ importância relativa de nossas universidades pode ser atestada com um rápido passeio por alguns dos principais rankings internacionais. Na publicação britânica The Times Higher Education Supplement, cujo ranking é o mais prestigiado internacionalmente, as universidades americanas e britânicas dominam a lista das 200 melhores instituições (84 instituições) e ocupam as 13 primeiras posições, com os Estados Unidos liderando com 33 universidades no top 100. A GrãBretanha aparece em segundo lugar com 15, seguida por Austrália e Holanda com sete cada. Suíça e França aparecem com cinco, enquanto Japão, Hong Kong, Canadá e Alemanha têm três centros universitários entre os melhores do planeta. A Universidade de São Paulo (USP), que em 2005 apareceu na 196- posição, não entrou na listagem das 200 melhores em 2006.

Na edição de 2006 de outro importante ranking internacional, o Academic Ranking of World Universities, desenvolvido pelo Institute of Higher Education da Universidade de Shanhai Jiao Tong, na China, e utilizado pelo The Economist, o Brasil entra com uma IES entre as 200 (USP na $153^{\star}$ posição). Na $302^{\star}$ posição, empatadas, aparecem a Unicamp e a UFRJ.

Os dois rankings, acima citados, têm por base tradicionais critérios acadêmicos relacionados ao ensino e à pesquisa. Outro critério é apresentado pelo Webometrics Ranking of the World Universities que trabalha com base no volume de conteúdos disponibilizados na Web e na visibilidade e no impacto desse material a partir do número de citações que recebe. Neste ranking, a USP aparece na $97^{2}$ posição. Num recorte que considera apenas as IES latino-americanas, a posição brasileira apresenta significativa melhora. Quarenta instituições aparecem entre as 100 melhores, sendo a USP a segunda colocada e a Unicamp a terceira.
} 
v permanece inalterada a brutal necessidade de expansão do ensino superior;

$\checkmark$ a acelerada expansão do setor privado, bem como a peculiar política nacional de incentivo à mercantilização do setor, faz do Brasil um caso desviante no mundo;

v entre as 100 melhores universidades do planeta, não há qualquer universidade brasileira; entre as 500 só existem três;

v o processo regulatório evolui a partir de uma memória estatal que não mais existe, mas no qual ainda se baseia, usando como parâmetro instrumentos toscos, como a definição de universidade da LDB, ou a triste restrição à diversidade institucional, como inscrita no Decreto no ${ }^{\circ} .860 / 2001$, revogado pelo Decreto no 5.733/2006, que mantém a mesma taxionomia restritiva da diversidade institucional;

v houve uma escolha pregressa de um modelo de formação superior estritamente profissionalizante;

v existe uma microrregulação baseada em portarias, despachos, pareceres, decretos, projetos de lei, todos submetidos à mesma lógica fundamental profissionalizante, sem nunca se discutir o fundamento do que se deseja para o futuro, ou o do que se ensina;

v o baixo volume de trabalho discente, associado à precária formação estritamente profissionalizante, constitui patamar insuficiente para a adequada formação de elites intelectuais, profissionais e científicas de classe mundial;

v constata-se uma ausência de cálculo estratégico na formulação de políticas públicas, através da tentativa de borrar, por via de instrumentos regulatórios, a fundamental distinção entre o público e privado no Brasil;

v inexiste uma fixação de patamares de excelência universitária compatíveis com os equivalentes das melhores universidades do planeta.

\section{Futuros alternativos}

Simplificações heurísticas permitidas, o futuro deveria vislumbrar políticas que permitissem:

v tirar vantagem e estimular a efetiva divisão social do trabalho institucional entre o setor público e o privado;

、 expandir aceleradamente a oferta de ensino superior, sem prejuízo da diversificação, com prioridade, do ponto de vista da massa do alunado, para 
a formação tecnológica e aplicada; aumentar corajosamente o número e a diversidade de diplomas oferecidos; indicar a perfeita e clara distinção prática e heurística entre educação pós-secundária e educação universitária;

- garantir que o governo brasileiro possa concentrar esforços e recursos na direção de assegurar a existência de um pequeno conjunto nacional de universidades de classe mundial;

v alternativamente, se for concluído que seria irracional, ou impossível do ponto de vista prático, investir em "universidades de classe mundial", por conta de nossas vicissitudes ideológicas que não têm apreço por diferenças, mas sim por isonomias, procurar garantir a existência de um amplo conjunto de departamentos ou institutos de qualidade mundial;

v alterar o aparato regulatório num conjunto de direções - primeiro, retirar da LDB a definição aritmética de universidade, bem como, idealmente, embora saiba ser impossível, retirar da Constituição aquela noção de indissociabilidade de ensino/pesquisa e extensão; segundo, permitir a maior e mais ampla diversidade de escolhas e alternativas institucionais, inclusive estimulando a experimentação, eliminando os decretos e projetos de lei que definem ex ante o que é cada instituição, aceitando, com a inevitável humildade intelectual, que não se pode definir ex ante formatos institucionais nunca experimentados;

v alterar as instâncias e instituições regulatórias, de modo a permitir que se diminua o peso da burocracia da administração direta, viabilizando, senão experimentando, arranjos governamentais mais adequados e flexíveis;

- estabelecer que precisamos simultaneamente de mais e de menos - precisamos de mais alternativas educacionais pós-secundárias pragmáticas e menos soluções uniformizantes; precisamos de mais estudo e mais trabalho acadêmico para os alunos que escolherem a opção verdadeiramente universitária, e menos anos de estudo para alunos de orientação aplicada ou profissionalizante;

v retirar da LDB a idéia de diretrizes curriculares nacionais; estas só fazem sentido num mundo empobrecido pela lógica da profissionalização precoce como o nosso, que pretende organizar o país ao longo de 43 leis profissionais, 43 "linguagens", ou 43 "impráticas" codificações da vida no planeta;

v dar mais liberdade, incentivar a experimentação institucional, restringir a regulação defensiva e passadista, procurando avaliar resultados, não precondições; 
v alterar uma série de padrões vigentes e "naturais", oferecendo mais educação aplicada e de orientação tecnológica, diminuindo, proporcionalmente, a supremacia acachapante das humanidades e das ciências sociais aplicadas no número total de estudantes de educação pós-secundária brasileira;

v oferecendo mais oportunidades e diplomas de estudos aplicados de curta duração, ampliando o sentido prático da educação pós-secundária e, simultaneamente, desprofissionalizando o primeiro ciclo da educação universitária, desta forma enfatizando claramente a distinção, bem como a complementaridade, entre educação pós-secundária aplicada e educação universitária;

- encurtando, enquanto simultaneamente os desprofissionaliza, os cursos universitários, hoje todos resumidos ao mínimo de quatro anos, estimulando, em inevitável e longuíssima negociação com as corporações legalizadas, a obtenção da licença profissional em ciclo pós-graduado;

v reforçando, financiando adequadamente e fazendo crescer dramaticamente o componente pós-graduado da educação universitária, inclusive de natureza profissional, conhecido entre nós como stricto sensu, a cargo da supervisão e da avaliação da Capes, de modo a trazer para a educação superior a musculatura acadêmica e a robusta avaliação controlada por comunidades de pares, "tecnologia" que é hoje perfeitamente controlada e dominada pela Capes, que foi capaz de criar, manter e estimular um altíssimo padrão de referência educacional, nunca obtido ou conseguido pelo sistema sob a tutela/supervisão da Sesu; trata-se portanto, de descortinar maneiras pelas quais a graduação brasileira possa se beneficiar de mecanismos assemelhados àqueles que são característicos da Capes, já que nos dias atuais a Sesu, quem sabe até o ministro da Educação, no que se refere às graduações, tende a se ocupar mais com sindicatos profissionais, corporações de ofício e entidades de representação de interesses profissionais e de mantenedores, enfim, se preocupar mais com um trabalho de resposta a pressões típicas da arena de representação de interesses, do que com questões propriamente acadêmicas;

- entendendo que o "sistema Sesu" tende a ser um sistema de massificação, que requer a adequada supervisão e verificação governamental, portanto, um "sistema de governo", até mesmo por conta de sua pesada agenda de resposta a interesses organizados, enquanto o "sistema Capes" tende a ser um sofisticado sistema de qualificação acadêmica e profissional controlado pelos pares, tanto cientistas quanto profissionais, num certo sentido independente do governo, exceto pelo fomento, e certa- 
mente independente da lógica sindicalizada ou de representação de interesses corporativos e empresariais, totalmente baseado em regras e referenciais acadêmicos, científicos e profissionais, de qualidade e padrões internacionais, portanto um "sistema da sociedade" ou melhor, do invisible college, da comunidade internacionalizada de scholars, cientistas, profissionais e acadêmicos.

\section{Referências bibliográficas}

BRENEMAN, David W.; PUSSER, Brian; TURNER, Sarah E. (Eds.). Earnings from learning: the rise of for-profit universities. Albany: State University of New York Press, 2006.

CHANANA, Karuna. Between the public and the private: Indian academics in transition. In: MEEK, V. Lynn; SUWANWELA, Charas. Higher education, research, and knowledge in the Asia-Pacific region. New York: Palgrave-Macmillan, 2006.

COELHO, Edmundo Campos. As profissões imperiais: advocacia, medicina e engenharia no Rio de Janeiro, 1822-1930. Rio de Janeiro: Record, 1999.

FARRINGTON, Dennis; PALFREYMAN, David (Eds.). The law of higher education. New York: Oxford University Press, 2006.

GOLDE, Chris M.; WALKER, George E. (Eds.). Envisioning the future of doctoral education: preparing stewards of the discipline. Stanford: The Carnegie Foundation for the Advancement of Teaching, 2006. (Carnegie Essays on the Doctorate).

IPEA. Brasil: o estado de uma nação - mercado de trabalho, emprego e informalidade. Brasília: Ipea, 2006.

KEZAR, Adrianna J.; CHAMBERS, Tony C.; BIRKHARDT, John C. (Eds.). Higher education for the public good: emerging voices from a national movement. San Francisco: JosseyBass, 2005.

KINSER, Kevin; LEVY, Daniel C. The for-profit sector: U.S. patterns and international echoes in higher education. Albany: Program for Research on Private Higher Education (Prophe), University at Albany: State University of New York, 2005. (Prophe Working Paper, n. 5).

LEVY, Daniel C. Unanticipated development: perspectives on private higher education's emerging roles. Albany: Program for Research on Private Higher Education (Prophe), University at Albany: State University of New York, 2002. (Prophe Working Paper, n. 1).

LOWI, Theodore. American business: public policy, case studies, and political theory. World Politics, n. 18, 1964. 
LYALL, K.; SELL, K. The true genius of America at risk: are we losing our public universities to de facto privatization? Westport: ACE/Praeger on Higher Education, 2006.

MAASSEN, Peter; OLSEN, Johan (Eds.). University dynamics and European integration. The Netherlands: Springer, 2007.

MAGALHÃES, André; NUNES, Edson; BARROSO, Helena Maria. Mensuração dos conteúdos acadêmicos da educação superior. Rio de Janeiro: Observatório Universitário, 2005. Disponível em: <www.observatoriouniversitario.org.br>. Acesso em: ago. 2007. (Documento de Trabalho, n. 42).

MARTIGNONI, Enrico. Restrições demográficas e socioeconômicas para a expansão do ensino superior: uma nota técnica. Rio de Janeiro: Observatório Universitário, 2007. (Documento de Trabalho n. 69).

McVEIGH, Brian J. Japanese higher education as myth. New York: M. E. Sharpe, 2002.

MEEK, V. Lynn; SUWANWELA, Charas. Higher education, research, and knowledge in the Asia-Pacific region. New York: Palgrave-Macmillan, 2006.

NOGUEIRA, André Magalhães. Universidades e pós-graduação no país. Rio de Janeiro: Observatório Universitário, 2007. (Documento de Trabalho n. 68).

NUNES, Edson. A divisão do trabalho e a rotina da pesquisa. Tese (Mestrado) - Iuperj, Rio de Janeiro, 1977.

; CARVALHO, Márcia Marques de. Ensino universitário, corporação e profissão: paradoxos e dilemas brasileiros. Revista Sociologias, Porto Alegre: UFRGS, v. 1, n. 1, jan./ jun. 2007.

; MARTIGNONI, Enrico; MOLHANO, Leandro. Economia política e regulação da educação superior no Brasil. In: XIMENES, Daniel de A. (Org.). Avaliação e regulação da educação superior: experiências e desafios. Brasília: Funadesp, 2005.

; NOGUEIRA, André; MOLHANO, Leandro. Futuros possíveis, passados indesejáveis: selo de qualidade da $\mathrm{OAB}$, provão e ensino superior no Brasil. Rio de Janeiro, Garamond, 2000.

; ___ C. Corporações, Estado e universidade: o diálogo compulsório sobre a duração de cursos superiores no Brasil. Rio de Janeiro: Observatório Universitário, 2003. Disponível em: <www.obsertoriouniversitario.org.br>. Acesso em: ago. 2007. (Documento de Trabalho n. 5).

et al. Teias de relações ambíguas: regulação e ensino superior. Brasília: Inep, 2000

OECD. Factbook, 2006: economic, environmental and social statistics. Paris, 2006. 
PERROW, Charles. Complex organizations. Glenview, Illinois: Scott, Foresman and Company, 1979.

PRIEST, Douglas M.; Sт. JOHN, Edward P. Privatization and public universities. Bloomington: Indiana University Press, 2006.

RUCH, Richard S. Higher Ed, Inc.: the rise of the for-profit university. Baltimore: The Johns Hopkins University Press, 2001.

SCOTT, Richard. Organizations: rational, natural, and open systems. Upper Saddle River: Prentice Hall, 1981.

SLAUGHTER, S.; RHOADES, G. Academic capitalism and the new economy: markets, state, and higher education. Baltimore: The Johns Hopkins University Press, 2004.

SPERLING, John. Rebel with a cause: the entrepreneur who created the University of Phoenix and the for-profit revolution in higher education. New York: John Wiley \& Sons, 2000.

TILAK, Jandhyala B. G. Private higher education: philanthropy to profits. In: Higher education in the world 2006: the financing of universities, New York: Palgrave Macmillan, 2006. (Guni Series on the Social Commitment of Universities, 1).

TROW, Martin. Problems in the transition from elite to mass higher education. In: OECD. Policies for higher education, from the General Report on the Conference on Future Structures of Post-Secondary Education. Paris: OECD, 1974. p. 55-101. 